TITLE:

\title{
Global meta-analysis for controlling factors on carbon stable isotope ratios of lotic periphyton.
}

AUTHOR(S):

Ishikawa, Naoto F; Doi, Hideyuki; Finlay, Jacques C

\section{CITATION:}

Ishikawa, Naoto F ...[et al]. Global meta-analysis for controlling factors on carbon stable isotope ratios of lotic periphyton.. Oecologia 2012, 170(2): 541-549

ISSUE DATE:

2012-10

URL:

http://hdl.handle.net/2433/160695

\section{RIGHT:}

The final publication is available at www.springerlink.com; This is not the published version. Please cite only the published version.; この論文 は出版社版でありません。引用の際には出版社版をご確認ご利用くだ さい。 
Ishikawa et al. Meta-analyses of lotic periphyton $\delta^{13} \mathrm{C}$

\title{
Global meta-analysis for controlling factors on
}

\section{carbon stable isotope ratios of lotic periphyton}

\author{
Naoto F. Ishikawa ${ }^{1{ }^{\star}}$, Hideyuki Doi ${ }^{2 \dagger}$, and Jacques C. Finlay ${ }^{3}$
}

Affiliations:

${ }^{1}$ Center for Ecological Research, Kyoto University, 2-509-3 Hirano Otsu Shiga 5202113 Japan

${ }^{2}$ Institute for Chemistry and Biology of the Marine Environment, Carl-von-Ossietzky

University Oldenburg, Schleusenstrasse 126382 Wilhelmshaven Germany

${ }^{3}$ Department of Ecology, Evolution and Behavior, University of Minnesota, 1987 Upper

Buford Circle St. Paul MN 55108 USA

${ }^{\dagger}$ Both authors contributed equally to this paper.

* Correspondence author: Naoto F. Ishikawa

e-mail: naoto-i@ecology.kyoto-u.ac.jp

telephone: +81775498240

fax: +81 775498201

${ }^{\S}$ Present address: Hideyuki Doi

Institute for Sustainable Sciences and Development, Hiroshima University, 1-3-1

Kagamiyama Higashi-Hiroshima Hiroshima 7398530 Japan 
Ishikawa et al. Meta-analyses of lotic periphyton $\delta^{13} \mathrm{C}$

Author Contributions: NFI and HD conceived and designed the study. JCF provided logical support. NFI, HD, JCF gathered and analyzed the data. NFI, HD, JCF wrote the manuscript. 
Ishikawa et al. Meta-analyses of lotic periphyton $\delta^{13} \mathrm{C}$

\section{Abstract}

Carbon stable isotope ratios $\left(\delta^{13} \mathrm{C}\right)$ are widely used to trace resource transfer pathway, yet $\delta^{13} \mathrm{C}$ variation of freshwater autotrophs has not been fully understood. We analyzed data from 42 published studies supplemented with some unpublished data to show the determinants of lotic periphyton $\delta^{13} \mathrm{C}$. At large spatial scales, we observed broad differences in periphyton $\delta^{13} \mathrm{C}$ among biomes and consistent longitudinal variation related to watershed area. Longitudinal increases in $\delta^{13} \mathrm{C}$ indicated the importance of in-stream processes on lotic carbon cycles and autotroph $\delta^{13} \mathrm{C}$ variation. At local spatial scales, periphyton $\delta^{13} \mathrm{C}$ was related negatively to canopy cover and water current velocity and positively to chlorophyll $a$ density. Autotroph $\delta^{13} \mathrm{C}$ varied among taxonomic groups. Cyanobacteria and red algae had significantly higher and lower $\delta^{13} \mathrm{C}$ than other taxa, respectively. A hierarchical model across spatial scales showed that local controls for periphyton $\delta^{13} \mathrm{C}$ were nested by regional controls, which suggested that productivity and $\mathrm{CO}_{2}$ availability determine $\delta^{13} \mathrm{C}$. Overall our results revealed general patterns of periphyton $\delta^{13} \mathrm{C}$ and provided improved information for study design and use of $\delta^{13} \mathrm{C}$ in isotopic mixing models in lotic food web studies.

Key words: $\delta^{13} C$ variation; regional control; local control; structural equation modeling; lotic ecosystem 
Ishikawa et al. Meta-analyses of lotic periphyton $\delta^{13} \mathrm{C}$

\section{Introduction}

Most ecosystems receive resource subsidization from other systems. Estimating contributions of spatial subsidies to organisms provides information of food web production and trophic structure via consideration of resource movement across ecosystem boundaries (Polis et al. 1997). Lotic food webs are a good example of subsidized systems, supported by two carbon sources: autochthonous (i.e., periphytic algae, mosses and other aquatic plants attaching to a substrate) and allochthonous (i.e., terrestrial litter and invertebrates, Nakano and Murakami 2001) resources. Distinguishing the contributions of these two sources to lotic food webs is challenging because direct observations of food sources are difficult. Carbon stable isotope ratios $\left(\delta^{13} \mathrm{C}\right)$ are widely used to discriminate between periphytic and terrestrial production in lotic ecosystems (e.g., Fry 1991; France 1995; Finlay 2001).

While the use of $\delta^{13} \mathrm{C}$ has many advantages as a natural tracer, growing awareness of the large spatial and temporal variability in $\delta^{13} \mathrm{C}$ values of lotic periphyton suggest limitation of $\delta^{13} \mathrm{C}$ applications under some circumstances (e.g., Finlay et al. 1999; Zah et al. 2001). Large variability in $\delta^{13} \mathrm{C}$ values of periphyton can make the isotopic baseline of food webs uncertain and consequently influence the accuracy of food web analysis (McCutchan and Lewis 2001; Zah et al. 2001). Since two-source mixing models require isotopic separation between potential sources, the variability in $\delta^{13} \mathrm{C}$ values of periphyton can compromise the precise estimation of the relative contribution of carbon sources to food webs. For example, Finlay et al. (1999) show large variations in $\delta^{13} \mathrm{C}$ values of periphyton and the herbivores over small spatial scales $(1-10 \mathrm{~m})$ in a stream related to in-situ water current velocity. Such effects greatly complicate mixing model applications.

Many previous studies have pointed out the importance of understanding the pattern of variability in $\delta^{13} \mathrm{C}$ values of lotic periphyton for the purpose of precise food web analysis 
Ishikawa et al. Meta-analyses of lotic periphyton $\delta^{13} \mathrm{C}$

(MacLeod and Barton 1998; Finlay et al. 1999; Trudeau and Rasmussen 2003; Singer et al. 2005; Doi et al. 2007; Hill et al. 2008). Although the importance of understanding the variability in periphyton $\delta^{13} \mathrm{C}$ is well recognized, the factors that determine $\delta^{13} \mathrm{C}$ values of periphyton are complex due to influences of spatial heterogeneity at multiple spatial scales such as local habitat, reach, and watershed (Doi et al. 2007). To understand the factors controlling periphyton $\delta^{13} \mathrm{C}$ values, both regional controls (e.g., biome or river size) and local controls (e.g., light/flow conditions, taxonomic composition) must be considered. These diverse controls over periphyton $\delta^{13} \mathrm{C}$ have not yet been adequately classified and brought into a hierarchically structured and causally plausible framework.

In this study, we conduct a global meta-analysis to identify the factors that determine the $\delta^{13} \mathrm{C}$ value of lotic periphyton. For this meta-analysis, we use a dataset including a total of 765 records from 42 references and some unpublished data. From the dataset, regional and local drivers hypothesized to affect periphyton $\delta^{13} \mathrm{C}$ are analyzed. Particularly we focus on biome, season, and watershed area as regional controls because they strongly affect periphytic production and dissolved inorganic carbon (DIC) availability in lotic ecosystems. Canopy cover, water current velocity, chlorophyll $a$ density, and dominant taxa in periphyton are used as local controls. Canopy cover regulates light intensity, chlorophyll $a$, and dominant taxa in periphyton, which controls DIC demand. Water current velocity regulates DIC availability for periphyton. Finally we build a hierarchical model and synthesize controlling pathways on periphyton $\delta^{13} \mathrm{C}$.

\section{Materials and methods}

\section{Data sources}

We searched for data for carbon stable isotope values of lotic periphyton from published 
Ishikawa et al. Meta-analyses of lotic periphyton $\delta^{13} \mathrm{C}$

sources using ISI Web of Science (http://www.isiknowledge.com). Search terms included 'periphyt*', 'algae', 'isotope', and 'stream'. The search was conducted on 24-Feb-2009 and returned 192 studies. We also added studies found in the journals Canadian Journal of Aquatic and Fisheries Science, Ecology, Freshwater Biology, Hydrobiologia, Journal of the North American Benthological Society, Limnology and Oceanography, and Marine and Freshwater Research that were not detected in our Web of Science search. Also, we included unpublished data from our own studies. For this analysis, we defined periphyton as predominantly algal material attached to solid surfaces. Attached autotrophic algae described by authors as benthic algae, epilithic algae, algal-dominated epilithon, filamentous algae, littoral algae, micro algae, epiphyton, periphytic biofilms, phototrophic biofilms, and phytomicrobenthos were regarded as periphyton in this meta-analysis. Data were used for epilithon only if authors specified the dominance of epilithic algae in the epilithic material. Neither periphyton nor epilithon are pure algae, and the terminology is not necessarily consistent among researchers. Some studies have defined epilithon as a mixed assemblage of algae, fungi, and bacteria (e.g., England and Rosemond 2004), and others regard epilithon as a surrogate of autochthonous materials (e.g., Watanabe et al. 2008) because they are highly influenced by polysaccharides derived from microalgal production (Lock 1993). Data for periphyton was often a mix of microalgae but information for specific taxonomic groups was extracted where possible. Data for macrophytes and aquatic bryophytes were also gathered.

We adopted the data that met following conditions:

i) The study was conducted in a field setting

ii) The study provided periphyton $\delta^{13} \mathrm{C}$ and environmental drivers

iii) The study did not use ${ }^{13} \mathrm{C}$ tracer additions 
Ishikawa et al. Meta-analyses of lotic periphyton $\delta^{13} \mathrm{C}$

When the data were presented in figures, we extracted data using graph digitizing software PlotDigitizer X ver. 2.0.1

(http://www.surf.nuqe.nagoya-u.ac.jp/ nakahara/Software/PlotDigitizerX/index-e.html). Finally, we selected 42 papers and used 765 data points.

\section{Explanatory variables}

Explanatory variables for periphyton $\delta^{13} \mathrm{C}$ were extracted from individual studies or, for a small number of cases, provided directly by authors. Biome (alpine; arctic; boreal; temperate; tropical), sampling season, and watershed area $\left(\mathrm{km}^{2}\right.$; hereafter, WA) of the study sites were used as "regional controls". We categorized biome of the study sites from the location of rivers studied. Sampling periods were categorized into groups approximating four seasons. The periods March-May, June-August, September-November, December-February corresponded to spring, summer, autumn, and winter for the Northern hemisphere while to autumn, winter, spring, and summer for the Southern hemisphere. The effects of seasonality on periphyton $\delta^{13} \mathrm{C}$ were categorized as a regional control because of strong relationship between season and productivity. Canopy cover percentage (\%; hereafter, CC), water current velocity ( $\mathrm{cm} \mathrm{s}^{-1}$; hereafter, WCV), chlorophyll $a$ density ( $\mathrm{mg} \mathrm{m}^{-2}$; hereafter, CHLA), and dominant taxa (bryophytes; cyanobacteria; diatoms; green algae; macrophytes; red algae; multiple taxa mixtures) were used as "local controls".

All numerical variables, excluding percent or categorical variables, were analyzed after transformation by $\log _{10} \mathrm{x}$ for WA and CHLA and by $\log _{10}(\mathrm{x}+1)$ for WCV because there were zero values in the WCV (Table 1), except for missing values. In the meta-analysis dataset, we did not have enough data for a statistically robust sample size for aqueous $\mathrm{CO}_{2}$ concentration and $\delta^{13} \mathrm{C}$ signatures, although these factors are important for determining $\delta^{13} \mathrm{C}$ 
Ishikawa et al. Meta-analyses of lotic periphyton $\delta^{13} \mathrm{C}$ of periphyton (Finlay 2004).

\section{Linear and non-linear modeling procedures}

We tested the relationships between periphyton $\delta^{13} \mathrm{C}$ and the potential explanatory variables. We analyzed the effects of "regional" and "local" controls separately by building two general linear models (GLMs) to test the relative contributions of potential explanatory variables to periphyton $\delta^{13} \mathrm{C}$ as follows:

Full model (regional controls):

$$
\text { Periphyton } \delta^{13} C=\text { Biome }+ \text { Season }+ \text { WA }
$$

Full model (local controls):

$$
\text { Periphyton } \delta^{13} C=C C+W C V+C H L A+\text { Dominant taxa }
$$

We selected the best GLM by downward stepwise selection according to the Akaike Information Criterion (AIC, Akaike 1974). We also calculated AIC differences $\left(\Delta_{i}\right)$ and Akaike weight $\left(\omega_{i}\right)$, which is considered as the weight of evidence in favor of a candidate model being the best model out of the set of models considered (Burnham and Anderson 2002). For the individual relationship between each explanatory variable and periphyton $\delta^{13} \mathrm{C}$, we compared both regressions of single linear and non-linear models with generalized cross validation (GCV) score. The smaller GCV score indicates higher fitness to the models (Wood 2008). Differences in periphyton $\delta^{13} \mathrm{C}$ among biomes, season, and dominant taxa were tested by post-hoc multiple comparison (Holm's test). For rivers that reported velocity data, the taxa-specific or river-specific relationships between periphyton $\delta^{13} \mathrm{C}$ and the water current velocity were analyzed using ANCOVA (dominant taxa and rivers as the covariance of each 
Ishikawa et al. Meta-analyses of lotic periphyton $\delta^{13} \mathrm{C}$

ANCOVA model; $\mathrm{n}=283$ ).

\section{Structural equation modeling procedure}

To consider hierarchical orders among regional and local controls, we used structural equation modeling $(\mathrm{SEM})$. The dataset $(\mathrm{n}=765)$ included four numerical variables (WA; CC; WCV; CHLA), and periphyton $\delta^{13} \mathrm{C}$. The SEM procedure for ecological studies is described in detail elsewhere (e.g., Shipley 2000; Grace 2006). Briefly, observed correlation matrix among the numerical variables was set to calculate a path-coefficient between two variables (see Appendix). Biome, season, and dominant taxa could not be included in the SEM because they were the nominal variables, which did not set reasonable correlation matrices.

To build a hierarchical model to explain periphyton $\delta^{13} \mathrm{C}$, we used a three step analyses using a correlation matrix among causal and response variables. First, non-hierarchical models that assumed all possible correlations between variables were examined. Second, all reasonable pathways among variables were included $a$ priori in the model. Third, we performed downward stepwise selection of the model judged by whether a path-coefficient was significant $(p<0.05)$ or not $(p>0.05)$ to arrive at the final model. The model fit to the data was assessed with the $\chi^{2}$ test (Grace 2006). The SEM approach logically and statistically takes account of multiple co-linearity among the numerical variables, and thus allows more direct identification of causal associations.

The significance level of all statistical tests was assessed at $\alpha=0.05$. We performed all statistical analyses and graphics using R ver. 2.13.1 software (R Development Core Team 2011) with DAAG (Maindonald and Braun 2011), MASS (Venables and Ripley 2002), mgcv (Wood 2011), and sem (Fox et al. 2010) packages in the library.

\section{Results}


Ishikawa et al. Meta-analyses of lotic periphyton $\delta^{13} \mathrm{C}$

\section{Variation in $\delta^{13} C$ signatures of periphyton}

Periphyton $\delta^{13} \mathrm{C}$ ranged from $-47.3 \%$ to $-9.3 \%$ (Fig. 1). The mean periphyton $\delta^{13} \mathrm{C}$ in the whole dataset was $-25.7 \pm 6.8 \%$ (Mean $\pm 1 \mathrm{SD}, \mathrm{n}=765)$. The most frequent values of periphyton $\delta^{13} \mathrm{C}(-28 \sim-26 \%$ ) overlapped with typical value of terrestrial C3 plants (Fig. 1); about $7 \%$ of the data fell into this range.

\section{Regional patterns and controls}

The model that had the lowest AIC value for regional controls included all explanatory variables (Table 2). We adopted the non-linear model as the best-fit model for the relationship between WA and periphyton $\delta^{13} \mathrm{C}$ (Fig. 2a) because it explained more variation than the linear model (GCV: 44.3 for non-linear, 47.5 for linear). There was a significant relationship between periphyton $\delta^{13} \mathrm{C}$ and WA (Df of smooth term $=5.69, \mathrm{R}^{2}=0.18, \mathrm{p}<0.001, \mathrm{n}=269$; Fig. 2a). Arctic and boreal rivers had significantly lower periphyton $\delta^{13} \mathrm{C}$ than other biomes (Holm's test: $\mathrm{p}<0.05$; Fig. 3a). Periphyton $\delta^{13} \mathrm{C}$ in winter was significantly higher than in spring and summer (Holm's test: $\mathrm{p}<0.001$; Fig. 3b).

\section{Local patterns and controls}

The model that had the lowest AIC value for local controls included canopy cover and dominant taxa, but $\Delta_{i}$ and $\omega_{i}$ values of the model were similar to those of the full model (Table 2). We again adopted the non-linear model as the best-fit model for the relationship between $\mathrm{CC}$ and periphyton $\delta^{13} \mathrm{C}$ (Fig. 2b) because it explained more variation than the linear model (GCV: 28.8 for non-linear, 39.1 for linear). There was a significant relationship between periphyton $\delta^{13} \mathrm{C}$ and CC (Df of smooth term $=6.33, \mathrm{R}^{2}=0.40, \mathrm{p}<0.001, \mathrm{n}=244$; Fig. $2 \mathrm{~b}$ ). Cyanobacteria (e.g., Nostoc) had significantly higher $\delta^{13} \mathrm{C}$ than other groups (Holm's test: $\mathrm{p}<$ 
Ishikawa et al. Meta-analyses of lotic periphyton $\delta^{13} \mathrm{C}$

0.001; Fig. 3c). Red algae (e.g., Batrachospermum and Lemanea) had significantly lower $\delta^{13} \mathrm{C}$ than the other taxa except bryophytes and macrophytes (Holm's test: $p<0.001$; Fig. $3 c$ ).

The effect of WCV on periphyton $\delta^{13} \mathrm{C}$ was significantly different among dominant taxa and rivers (ANCOVA; dominant taxa: $\mathrm{p}<0.001$, rivers studied: $\mathrm{p}<0.001$, the interaction: $\mathrm{WCV}^{*}$ dominant taxa: $\mathrm{p}=0.59, \mathrm{WCV} *$ rivers: $\left.\mathrm{p}=0.048\right)$. The $\delta^{13} \mathrm{C}$ values of cyanobacteria and bulk periphyton (multiple taxa mixtures) had significantly negative relationships with $\mathrm{WCV}$ (cyanobacteria: slope $=-4.2, \mathrm{R}^{2}=0.26, \mathrm{p}=0.01, \mathrm{n}=22$; multiple taxa mixtures: slope $=-1.8, \mathrm{R}^{2}=0.02, \mathrm{p}=0.04, \mathrm{n}=200$ ), while other taxa did not (diatoms: $\mathrm{p}$ $=0.92, \mathrm{n}=19$; green algae: $\mathrm{p}=0.09, \mathrm{n}=42$; bryophyte, macrophyte, red algae: no data) (Fig. 2c). The relationship between CHLA and periphyton $\delta^{13} \mathrm{C}$ was significantly positive (slope $=$ $3.7, \mathrm{R}^{2}=0.08, \mathrm{p}<0.001, \mathrm{n}=204$; Fig. $\left.2 \mathrm{~d}\right)$.

\section{Structural equation modeling}

The SEM returned three models, though we presented only the final reduced model that contained only significant path-coefficients. Non-hierarchical null model indicated that three variables (CC, WCV, and CHLA) significantly influenced periphyton $\delta^{13} \mathrm{C}$. The path-coefficient between WA and periphyton $\delta^{13} \mathrm{C}$ was not significantly different from zero ( $\mathrm{p}$ $=0.45)$. All explanatory variables were significantly correlated with each other, indicating that they were not completely independent. Since GLM results showed that WA was a strong regional control, the null model suggested that WA affected periphyton $\delta^{13} \mathrm{C}$ through regulating other local controls.

A hierarchical model that contained all reasonable pathways was saturated (i.e., $\mathrm{df}=$ 0). The model indicated that WA occupied the top level of the hierarchy, controlling all other variables but a direct path from WA to periphyton $\delta^{13} \mathrm{C}$ was not significantly different from zero $(\mathrm{p}=0.45)$. Path-coefficients from WA to $\mathrm{CC}, \mathrm{WCV}$, and CHLA were all significantly 
Ishikawa et al. Meta-analyses of lotic periphyton $\delta^{13} \mathrm{C}$

different from zero $(\mathrm{p}<0.001)$. CC and WCV occupied the same layer, both significantly controlling CHLA. There was no correlation between CC and WCV $(p=0.36)$. CHLA occupied the lowest level of the hierarchy. CC, WCV, and CHLA had significant paths to periphyton $\delta^{13} \mathrm{C}(\mathrm{p}<0.001)$.

Downward stepwise selection based on $\mathrm{p}$ values deleted insignificant paths in saturated model. Direct regression from WA to periphyton $\delta^{13} \mathrm{C}$ was not significant, but WA strongly regulated local CC and CHLA, which controlled periphyton $\delta^{13} \mathrm{C}$ (Fig. 4). Correlation between CC and WCV was also deleted from the model. Insignificant $\chi^{2}(\mathrm{p}>$ 0.05) indicated that the model provided an acceptable fit to the data (Grace 2006).

\section{Discussion}

The mean $\delta^{13} \mathrm{C}$ value of periphyton in various lotic ecosystems is close to or overlaps that of terrestrial litter for $\mathrm{C} 3$ plants. However, large variations in periphyton $\delta^{13} \mathrm{C}$ are evident such that periphyton $\delta^{13} \mathrm{C}$ are distinct from terrestrial sources in many streams and rivers. Below, we integrate understanding of regional and local controls of periphyton $\delta^{13} \mathrm{C}$ into a hierarchical framework, which is useful in designing studies with carbon stable isotopic techniques.

\section{Regional patterns and controls}

Significant $\delta^{13} \mathrm{C}$ difference among biomes suggests that variation in stream productivity controls, at least in part, fractionation of ${ }^{13} \mathrm{C}$ in photosynthesis. Although often unshaded by terrestrial vegetation, arctic and boreal rivers have low water temperatures and are nutrient poor, resulting in very low rates of primary productivity (Peterson et al. 1986). Low primary production promotes discrimination against ${ }^{13} \mathrm{CO}_{2}$ during photosynthesis (Finlay 2001). 
Ishikawa et al. Meta-analyses of lotic periphyton $\delta^{13} \mathrm{C}$

Isotopic fractionation is thus likely larger, resulting in lower periphyton $\delta^{13} \mathrm{C}$ in arctic and boreal rivers than in other biomes. Alpine rivers often have little canopy shading and show higher $\delta^{13} \mathrm{C}$ than rivers in arctic and boreal biomes, probably owing to higher $\delta^{13} \mathrm{C}$ of DIC and/or higher primary production (e.g., McCutchan and Lewis 2001; Zah et al. 2001).

An influence of primary production is also likely to underlie the positive relationship between watershed area and periphyton $\delta^{13} \mathrm{C}$. Gross primary production increases with watershed area due to channel widening, nutrient loading, and increased light availability (Battin et al. 2008; Bernot et al. 2010; Finlay 2011). Thus, photosynthetic activity generally increases with river size, while $\mathrm{CO}_{2}$ concentrations tend to decrease due to uptake and degassing (Finlay 2003; Butman and Raymond 2011). These changes increase carbon limitation effects on isotopic fractionation in productive rivers, leading to the pattern of increasing periphyton $\delta^{13} \mathrm{C}$ with river size (Finlay 2001).

Primary production increases in deciduous forest rivers during winter, because seasonal defoliation reduces canopy cover (Roberts et al. 2007). Canopy opening increases primary production, resulting in smaller fractionation and higher $\delta^{13} \mathrm{C}$. Seasonality in periphyton $\delta^{13} \mathrm{C}$ has been reported for studies conducted in alpine and temperate rivers (e.g., McCutchan and Lewis 2001; Finlay 2004). Since our dataset was biased towards temperate rivers, the seasonal influence we observed is most relevant to temperate biomes. We did not have enough data to address the mechanisms driving relationships with seasonality. The patterns shown here indicate that regional influences on in-stream productivity and possibly watershed biogeochemistry are controlling periphyton $\delta^{13} \mathrm{C}$ variation.

\section{Local patterns and controls}

Periphyton $\delta^{13} \mathrm{C}$ was lower under highly shaded, low light conditions. Moreover, a positive relationship was observed between chlorophyll $a$ density and periphyton $\delta^{13} \mathrm{C}$. Both results 
Ishikawa et al. Meta-analyses of lotic periphyton $\delta^{13} \mathrm{C}$

support the hypothesis that algal photosynthetic activity determines isotopic fractionation between DIC and algal cells. Photosynthetic activity decreases with increased canopy cover because of low light availability and colder temperature for primary producers, leading to greater isotopic fractionation (Behmer and Hawkins 1986; Lamberti and Steinman 1997; Finlay 2011). Thus decreasing periphyton $\delta^{13} \mathrm{C}$ with increased canopy cover indicates that there is considerable isotopic discrimination against ${ }^{13} \mathrm{CO}_{2}$ between aqueous $\mathrm{CO}_{2}$ and algae during photosynthesis, or possibly less $\mathrm{HCO}_{3}{ }^{-}$use by algae in shaded habitats (Doi et al. 2007; Finlay 2004; Hill and Middleton 2006; Hill et al. 2008).

The negative relationship between water current velocity and periphyton $\delta^{13} \mathrm{C}$ values suggests that the increased $\mathrm{CO}_{2}$ supply to algal cells with high water current velocity allows more selective ${ }^{12} \mathrm{CO}_{2}$ uptake by algae, intensifying the isotopic fractionation between aqueous $\mathrm{CO}_{2}$ and periphyton (MacLeod and Barton 1998; Finlay et al. 1999; Trudeau and Rasmussen 2003; Singer et al. 2005). Although field and laboratory studies have often observed that faster current velocity strongly decreases periphyton $\delta^{13} \mathrm{C}$, the general influence of water velocity on periphyton $\delta^{13} \mathrm{C}$ was weaker in the meta-analyses than for individual studies. This difference may exist because the flow history, rather than the instantaneous current velocity, is more influential to $\delta^{13} \mathrm{C}$ at sites with variable hydrograph conditions (Singer et al. 2005). Overall, water current velocity effects on periphyton $\delta^{13} \mathrm{C}$ values must be considered with other environmental variables.

Our analyses show that variation in physiology among taxa exerts a strong influence on patterns of ${ }^{13} \mathrm{C}$ fractionation. Cyanobacteria typically concentrate inorganic carbon more efficiently than any other group, and are thus able to use $\mathrm{HCO}_{3}{ }^{-}$under low water current velocity (Merz-Preiß and Riding 1999; Badger 2003). The $\delta^{13} \mathrm{C}$ value of $\mathrm{HCO}_{3}{ }^{-}$is higher than that of aqueous $\mathrm{CO}_{2}$ (Mook et al. 1974) explaining the higher $\delta^{13} \mathrm{C}$ of cyanobacteria compared to all other taxa examined. In contrast, red algae and bryophytes had 
Ishikawa et al. Meta-analyses of lotic periphyton $\delta^{13} \mathrm{C}$

lower $\delta^{13} \mathrm{C}$ than other taxa. For red algae, isotopic discrimination during inner-cell carbon transportation is large, as most red algae cannot concentrate inorganic carbon within their cells (Raven et al. 2005). Furthermore, most bryophytes cannot use $\mathrm{HCO}_{3}{ }^{-}$as photosynthetic substrate (Prins and Elzenga 1989). Significant $\delta^{13} \mathrm{C}$ difference among taxa suggests that the researchers should pay attention to the community structure in freshwater autotroph.

\section{Relationships between regional and local controls}

Our hierarchical model shows that multilevel-controls determine periphyton $\delta^{13} \mathrm{C}$. The effect of watershed area on periphyton $\delta^{13} \mathrm{C}$ was indirect in our model. Increasing watershed area is associated with higher discharge, channel widening, and reduced canopy shading above the water surface. Thus watershed area controls canopy cover and water current velocity on average, which locally control periphyton $\delta^{13} \mathrm{C}$. The significant direct paths from watershed area to chlorophyll $a$ density suggests that large rivers can support higher biomass of periphyton, probably because of greater light and nutrient availability.

The model is closely related to the structure of geomorphology and productivity in lotic ecosystems (e.g., Vannote et al. 1980), indicating that periphyton $\delta^{13} \mathrm{C}$ changes along with river continuum through several different pathways. In a food web context, a recent study showed that $\delta^{13} \mathrm{C}$ gradients of macroinvertebrates from upland to lowland rivers reflect longitudinal patterns of their resource base (Kobayashi et al. 2011). Variability in periphyton $\delta^{13} \mathrm{C}$ across multiple spatial scales is clearly transferred to the lotic food webs, showing the importance of multiscale analyses for understanding food web dynamics using $\delta^{13} \mathrm{C}$ signatures in fluvial networks.

In the dataset, however, the low $\mathrm{R}^{2}$ values of both non-hierarchical and hierarchical models suggest that unexplained $\delta^{13} \mathrm{C}$ variation in lotic periphyton remains. Lack of data for dissolved $\mathrm{CO}_{2}$ concentration and/or $\delta^{13} \mathrm{C}$ values of DIC in study sites might limit our 
Ishikawa et al. Meta-analyses of lotic periphyton $\delta^{13} \mathrm{C}$

modeling approach for prediction of periphyton $\delta^{13} \mathrm{C}$. For example, the positive relationship between watershed area and periphyton $\delta^{13} \mathrm{C}$ may reflect lower $\mathrm{CO}_{2}$ concentration in large rivers (Finlay 2003; Butman and Raymond 2011). DIC $\delta^{13} \mathrm{C}$ variation may also have been important since values typically range between $-13 \%$ to $-9 \%$ across most rivers (Finlay 2003).

Since periphyton carbon has longer turnover time than aqueous $\mathrm{CO}_{2}$ and $\mathrm{HCO}_{3}{ }^{-}$, $\delta^{13} \mathrm{C}$ of periphyton integrates short-term fluctuation in DIC $\delta^{13} \mathrm{C}$ caused by variation in discharge (Finlay 2003; Doctor et al. 2008). Such fluctuations are about 2-4\%o, much smaller than observed variation in periphyton $\delta^{13} \mathrm{C}$ (i.e., $~ 15 \%$ ) at small scales. In addition to the effect of DIC, short-term variations in water current velocity and primary production may also be important for periphyton $\delta^{13} \mathrm{C}$ (France and Cattaneo 1998; Singer et al. 2005). Finer resolution studies, rather than global meta-analysis, are thus required to address temporal variation in periphyton $\delta^{13} \mathrm{C}$.

\section{Perspectives for food web studies}

While a global model to predict specific $\delta^{13} \mathrm{C}$ values of periphyton was beyond the scope of this study, our analyses provides information on the likelihood of overlap or isotopic separation of organic matter sources. In settings where $\delta^{13} \mathrm{C}$ value of periphyton are most likely to overlap with that of terrestrial litter, alternative methods can be used to avoid expense associated with extensive sampling for $\delta^{13} \mathrm{C}$. We suggest use of alternative isotopes such as carbon-14 natural abundance $\left(\Delta^{14} \mathrm{C}\right)$, and sulfur and hydrogen stable isotopes to identify the food web structure and energy sources (Doi et al. 2006; Finlay et al. 2010; Ishikawa et al. 2010). For example, the $\Delta^{14} \mathrm{C}$ value of periphyton is corrected by $\delta^{13} \mathrm{C}$ and therefore is not affected by isotopic fractionation (Ishikawa et al. 2012). These isotope tracers may in some situations provide better estimation of food web attributes than $\delta^{13} \mathrm{C}$. The 
Ishikawa et al. Meta-analyses of lotic periphyton $\delta^{13} \mathrm{C}$

combined use of such alternative isotopes with $\delta^{13} \mathrm{C}$ analysis will be helpful for better understanding of carbon source contribution to freshwater food webs. 
Ishikawa et al. Meta-analyses of lotic periphyton $\delta^{13} \mathrm{C}$

\section{Acknowledgments}

We thank CM Godwin and AW Walters for providing their unpublished data for the meta-analysis. Comments from RO Hall and an anonymous reviewer greatly improved early draft of this manuscript. H Doi and NF Ishikawa were financially supported by the Japan Society for the Promotion of Science to conduct this study. 
Ishikawa et al. Meta-analyses of lotic periphyton $\delta^{13} \mathrm{C}$

\section{References}

Akaike H (1974) A new look at the statistical model identification. IEEE Trans Autom Control 19:716-723

Badger $\mathrm{M}$ (2003) The roles of carbonic anhydrases in photosynthetic $\mathrm{CO}_{2}$ concentrating mechanisms. Photosynth Res 77:83-94

Battin TJ, Kaplan LA, Findlay S, Hopkinson CS, Marti E, Packman AI, Newbold JD, Sabater F (2008) Biophysical controls on organic carbon fluxes in fluvial networks. Nat Geosci $1: 95-100$

Behmer DJ, Hawkins CP (1986) Effects of overhead canopy on macroinvertebrate production in a Utah stream. Freshw Biol 16:287-300

Bernot MJ, Sobota DJ, Hall RO Jr, Mulholland PJ, Dodds WK, Webster JR, Tank JL, Ashkenas LR, Cooper LW, Dahm CN, Gregory SV, Grimm NB, Hamilton SK, Johnson, SL, McDowell WH, Meyer JL, Peterson B, Poole GC, Valett HM, Arango C, Beaulieu JJ, Burgin AJ, Crenshaw C, Helton AM, Johnson L, Merriam J, Niederlehner BR, O’Brien JM, Potter JD, Sheibley RW, Thomas SM, Wilson K (2010) Inter-regional comparison of land-use effects on stream metabolism. Freshw Biol 55:1874-1890

Burnham KP, Anderson RD (2002) Model selection and multimodel inference: a practical information-theoretic approach. Springer, New York

Butman D, Raymond PA (2011) Significant efflux of carbon dioxide from streams and rivers in the United States. Nat Geosci 4:839-842

Doctor DH, Kendall C, Sebestyen SD, Shanley JB, Ohte N, Boyer EW (2008) Carbon isotope fractionation of dissolved inorganic carbon (DIC) due to outgassing of carbon dioxide from a headwater stream. Hydrol Process 22:2410-2423

Doi H, Takagi A, Mizota C, Okano J, Nakano S, Kikuchi E (2006) Contribution of 
Ishikawa et al. Meta-analyses of lotic periphyton $\delta^{13} \mathrm{C}$

chemoautotrophic productions to the freshwater macroinvertebrates in a headwater stream using multiple stable isotopes. Internat Rev Hydrobiol 91:501-508

Doi H, Takemon Y, Ohta T, Ishida Y, Kikuchi E (2007) Effects of reach-scale canopy cover on trophic pathways of caddisfly larvae in a Japanese mountain stream. Mar Freshw Res $58: 811-817$

England LE, Rosemond AD (2004) Small reductions in forest cover weaken terrestrial-aquatic linkages in headwater streams. Freshw Biol 49:721-734

Finlay JC (2001) Stable-carbon-isotope ratios of river biota: implications for energy flow in lotic food webs. Ecology 82:1052-1064

Finlay JC (2003) Controls of streamwater dissolved inorganic carbon dynamics in a forested watershed. Biogeochemistry 62:231-252

Finlay JC (2004) Patterns and controls of lotic algal stable carbon isotope ratios. Limnol Oceanogr 49:850-861

Finlay JC (2011) Stream size and human influences on ecosystem production in river networks. Ecosphere 2:art87. doi:10.1890/ES11-00071.1

Finlay JC, Power ME, Cabana G (1999) Effects of water velocity on algal carbon isotope ratios: implications for river food web studies. Limnol Oceanogr 44:1198-1203

Finlay JC, Khandwala S, Power ME (2002) Spatial scale of carbon flow in a river food web. Ecology 83:1845-1859

Finlay JC, Doucett RR, McNeely C (2010) Tracing energy flow in stream food webs using stable isotopes of hydrogen. Freshw Biol 55:941-951

Fox J, Kramer A, Friendly M (2010) sem: Structural Equation Models. R package version $0.9-21$

France R, Cattaneo A (1998) $\delta^{13} \mathrm{C}$ variability of benthic algae: effects of water colour via modulation by stream current. Freshw Biol 39:617-622 
Ishikawa et al. Meta-analyses of lotic periphyton $\delta^{13} \mathrm{C}$

Fry B (1991) Stable isotope diagrams of freshwater food webs. Ecology 72:2293-2297

Grace JB (2006) Structural equation modeling and natural systems. Cambridge University Press, Cambridge

Hill WR, Middleton RG (2006) Changes in carbon stable isotope ratios during periphyton development. Limnol Oceanogr 51:2360-2369

Hill WR, Fanta SE, Roberts BJ (2008) ${ }^{13} \mathrm{C}$ dynamics in benthic algae: Effects of light, phosphorus, and biomass development. Limnol Oceanogr 53:1217-1226

Ishikawa NF, Uchida M, Shibata Y, Tayasu I (2010) A new application of radiocarbon concentrations $\left({ }^{14} \mathrm{C}\right)$ to stream food web analysis. Nucl Instrum Methods Phys Res Sect B-Beam Interact Mater Atoms 268:1175-1178

Ishikawa NF, Uchida M, Shibata Y, Tayasu I (2012) Natural C-14 provides new data for stream food web studies: a comparison with C-13 in multiple stream habitats. Mar Freshw Res 63:210-217

Kobayashi S, Akamatsu F, Amano K, Nakanishi S, Oshima Y (2011) Longitudinal changes in $\delta^{13} \mathrm{C}$ of riffle macroinvertebrates from mountain to lowland sections of a gravel-bed river. Freshw Biol 56:1434-1446

Lamberti GA, Steinman AD (1997) A comparison of primary production in stream ecosystems. J N Am Benthol Soc 16:95-103

Lock MA (1993) Attached microbial community in rivers. In: Ford TE (ed) Aquatic microbiology: an ecological approach. Blackwell, Boston, pp 113-138

MacLeod NA, Barton DR (1998) Effects of light intensity, water velocity, and species composition on carbon and nitrogen stable isotope ratios in periphyton. Can J Fish Aquat Sci 55:1919-1925

Maindonald J, Braun WJ (2011) DAAG: Data Analysis And Graphics data and functions. R package version 1.08 
Ishikawa et al. Meta-analyses of lotic periphyton $\delta^{13} \mathrm{C}$

McCutchan JH Jr., Lewis WM Jr. (2001) Seasonal variation in stable isotope ratios of stream algae. Verh Internat Verein Limnol 27:3304-3307

Merz-Preiß M, Riding R (1999) Cyanobacterial tufa calcification in two freshwater streams: ambient environment, chemical thresholds and biological processes. Sediment Geol 126:103-124

Mook WG, Bommerson JC, Staverman WH (1974) Carbon isotope fractionation between dissolved bicarbonate and gaseous carbon dioxide. Earth Planet Sci Let 22:169-176

Nakano S, Murakami M (2001) Reciprocal subsidies: dynamic interdependence between terrestrial and aquatic food webs. Proc Natl Acad Sci USA 98:166-170

Peterson BJ, Hobbie JE, Corliss TL (1986) Carbon flow in a tundra stream ecosystem. Can J Fish Aquat Sci 43:1259-1270

Polis GA, Anderson WB, Holt RD (1997) Toward an integration of landscape and food web ecology: the dynamics of spatially subsidized food webs. Annu Rev Ecol Evol Syst 28:289-316

Prins, HBA, Elzenga JTM (1989) Bicarbonate utilization: Function and mechanism. Aquat Bot 34:59-83

Rasmussen JB, Trudeau V (2007) Influence of velocity and chlorophyll standing stock on periphyton $\delta^{13} \mathrm{C}$ and $\delta^{15} \mathrm{~N}$ in the Ste. Marguerite River system, Quebec. Can J Fish Aquat Sci 64:1370-1381

Rau GH, Riebesell U, Wolf-Gladrow D (1996) A model of photosynthetic ${ }^{13} \mathrm{C}$ fractionation by marine phytoplankton based on diffusive molecular $\mathrm{CO}_{2}$ uptake. Mar Ecol Prog Ser $133: 275-285$

Raven JA, Ball LA, Beardall J, Giordano M, Maberly SC Algae lacking carbon-concentrating mechanisms. Can J Bot 83:879-890

R Development Core Team (2011) R: A language and environment for statistical computing. 
Ishikawa et al. Meta-analyses of lotic periphyton $\delta^{13} \mathrm{C}$

R Foundation for Statistical Computing, Vienna, Austria. ISBN 3-900051-07-0, URL http://www.R-project.org.

Roberts BJ, Mulholland PJ, Hill WR (2007) Multiple scales of temporal variability in ecosystem metabolism rates: results from 2 years of continuous monitoring in a forested headwater stream. Ecosystems 10:588-606

Shipley B (2000) Cause and correlation in biology: a user's guide to path analysis, structural equations and causal inference. Cambridge University Press, Cambridge

Singer GA, Panzenböck M, Weigelhofer G, Marchesani C, Waringer J, Wanek W, Battin TJ (2005) Flow history explains temporal and spatial variation of carbon fractionation in stream periphyton. Limnol Oceanogr 50:706-712

Trudeau V, Rasmussen JB (2003) The effect of water velocity on stable carbon and nitrogen isotope signatures of periphyton. Limnol Oceanogr 48:2194-2199

Vannote RL, Minshall GW, Cummins KW, Sedell JR, Cushing CE (1980) The river continuum concept. Can J Fish Aquat Sci 37:130-137

Venables WN, Ripley BD (2002) Modern applied statistics with S. 4th edn. Springer, New York

Watanabe K, Monaghan MT, Takemon Y, Omura T (2008) Biodilution of heavy metals in a stream macroinvertebrate food web: Evidence from stable isotope analysis. Sci Total Environ 394:57-67

Wood SN (2008) Fast stable direct fitting and smoothness selection for generalized additive models. J R Stat Soc B 70:495-518

Wood SN (2011) Fast stable restricted maximum likelihood and marginal likelihood estimation of semiparametric generalized linear models. J R Stat Soc B 73:3-36

Zah R, Burgherr P, Bernasconi SM, Uehlinger U (2001) Stable isotope analysis of macroinvertebrates and their food sources in a glacier stream. Freshw Biol 46:871-882 
Ishikawa et al. Meta-analyses of lotic periphyton $\delta^{13} \mathrm{C}$ 1 
Ishikawa et al. Meta-analyses of lotic periphyton $\delta^{13} \mathrm{C}$

2 Table 1:

3 Summary of variables with abbreviation, type of data, units, category, and statistical transformation for modeling.

\begin{tabular}{|c|c|c|c|c|c|c|}
\hline Control & Variable & Abbreviation & Type of data & Unit & Category & $\begin{array}{l}\text { Statistical } \\
\text { transformation }\end{array}$ \\
\hline \multirow[t]{3}{*}{ Regional } & Biome & & Categorical & & Alpine; Arctic; Boreal; Temperate; Tropical & \\
\hline & Season & & Categorical & & Spring; Summer; Autumn; Winter & \\
\hline & Watershed area & WA & Numerical & $\mathrm{km}^{2}$ & & $\log _{10} x$ \\
\hline \multirow[t]{4}{*}{ Local } & Canopy cover & $\mathrm{CC}$ & Numerical & $\%$ & & NA \\
\hline & $\begin{array}{l}\text { Water current } \\
\text { velocity }\end{array}$ & WCV & Numerical & $\mathrm{cm} \mathrm{s}^{-1}$ & & $\log _{10}(\mathrm{x}+1)$ \\
\hline & $\begin{array}{l}\text { Chlorophyll } a \\
\text { density }\end{array}$ & CHLA & Numerical & $\mathrm{mg} \mathrm{m}^{-2}$ & & $\log _{10} \mathrm{x}$ \\
\hline & Dominant taxa & & Categorical & & $\begin{array}{l}\text { Bryophytes; Cyanobacteria; Diatoms; } \\
\text { Green algae; Macrophytes; Red algae; } \\
\text { Multiple taxa mixtures }\end{array}$ & \\
\hline
\end{tabular}


Ishikawa et al. Meta-analyses of lotic periphyton $\delta^{13} \mathrm{C}$

5 Table 2: Stepwise tests for regional and local controls to explain periphyton $\delta^{13}$ C. $\Delta_{i}$ and $\omega_{i}$

6 were AIC differences and Akaike weights, respectively.

\begin{tabular}{lcccccc}
\hline & Df & Sum of sq & RSS & AIC & $\Delta_{i}$ & $\omega_{i}$ \\
\hline Regional controls & & & & & & \\
Full model & & & 8997 & 964.2 & & 0.999 \\
+ WA + Biome & 4 & 897.2 & 9894 & 981.8 & 17.6 & $<0.001$ \\
+ Season + Biome & 1 & 1957.1 & 10954 & 1015.1 & 50.9 & $<0.001$ \\
+ WA + Season & 4 & 2810 & 11807 & 1029.3 & 65.1 & $<0.001$ \\
& & & & & & \\
Local controls & & & & & & \\
+ Dominant taxa + WCV + CC & 1 & 5.1 & 2447 & 365.8 & & 0.48 \\
+ Dominant taxa + CHL + CC & 1 & 21.6 & 2463 & 366.6 & 0.8 & 0.32 \\
Full model & & & 2441 & 367.5 & 1.7 & 0.20 \\
+ CC + WCV + CHLA & 1 & 270.6 & 2712 & 377.9 & 12.1 & $<0.001$ \\
+ Dominant taxa + WCV + & 1 & 666.2 & 3108 & 394.0 & 28.2 & $<0.001$ \\
CHLA & & & & & & \\
\hline
\end{tabular}

7 
Ishikawa et al. Meta-analyses of lotic periphyton $\delta^{13} \mathrm{C}$

Figure 4:

Figure 1:

Figure 2:

\section{Figure 3:}

Frequency of $\delta^{13} \mathrm{C}$ of lotic periphyton (\%o, mean: $-25.7 \%$, SD: $6.8, \mathrm{n}=765$ ). The black bar indicates overlap with typical values of terrestrial C3 plants $(-28 \sim-26 \%$ o)

Relationships between periphyton $\delta^{13} \mathrm{C}(\% \mathrm{o})$ and a) watershed area (WA: $\left.\mathrm{km}^{2}, \mathrm{n}=269\right)$, b) canopy cover $(\mathrm{CC}: \%, \mathrm{n}=244), \mathrm{c})$ water current velocity (WCV: $\left.\mathrm{cm} \mathrm{s}^{-1}, \mathrm{n}=283\right)$, and d) chlorophyll $a$ density (CHLA: $\mathrm{mg} \mathrm{m}^{-2}, \mathrm{n}=204$ ). The lines of a) and b) are given by smooth spline regression. The purple dashed line of c) is given by linear regression for $\delta^{13} \mathrm{C}$ of cyanobacteria. The black lines of c) and d) are given by linear regression for $\delta^{13} \mathrm{C}$ of multiple taxa mixtures. Color version available online

Box plot for periphyton $\delta^{13} \mathrm{C}(\%)$ and a) biome (Alpine: $\mathrm{n}=30$, Arctic: $\mathrm{n}=19$, Boreal: $\mathrm{n}=$ 104, Temperate: $\mathrm{n}=570$, Tropical: $\mathrm{n}=42$ ), b) season (Spring: $\mathrm{n}=87$, Summer: $\mathrm{n}=329$, Autumn: $\mathrm{n}=95$, Winter: $\mathrm{n}=114$ ), and c) dominant taxa (Bryophytes: $\mathrm{n}=16$, Cyanobacteria: $\mathrm{n}=46$, Diatoms: $\mathrm{n}=52$, Green algae: $\mathrm{n}=94$, Macrophytes: $\mathrm{n}=8$, Red algae: $\mathrm{n}=22$, Multiple taxa mixtures: $\mathrm{n}=527)$. The box and bar depict inter-quartile (Q1 and 3) and median, respectively. The whisker represents the most extreme data point that is no more than 1.5 times the inter-quartile. Outliers are shown where applicable

Path-diagram containing only significant paths. For the non-hierarchical null model 
Ishikawa et al. Meta-analyses of lotic periphyton $\delta^{13} \mathrm{C}$

34 (including multiple linear regression model), and for the full model with all reasonable

35 combinations of paths, see Appendix. The numbers near each arrow indicate the standardized

36 path-coefficient. One-sided arrows indicate causality. Solid and dashed arrows indicate

37 positive and negative relationships, respectively, and arrow thickness is scaled to the

38 path-coefficient value. "e" represents unexplained variance of dependent variables.

39 Insignificant $\chi^{2}$ of $1.40(\mathrm{df}=2, \mathrm{n}=765, \mathrm{p}=0.50)$ indicates that the model provides an

40 acceptable fit to the data (Grace 2006)

41 
Ishikawa et al. Meta-analyses of lotic periphyton $\delta^{13} \mathrm{C}$

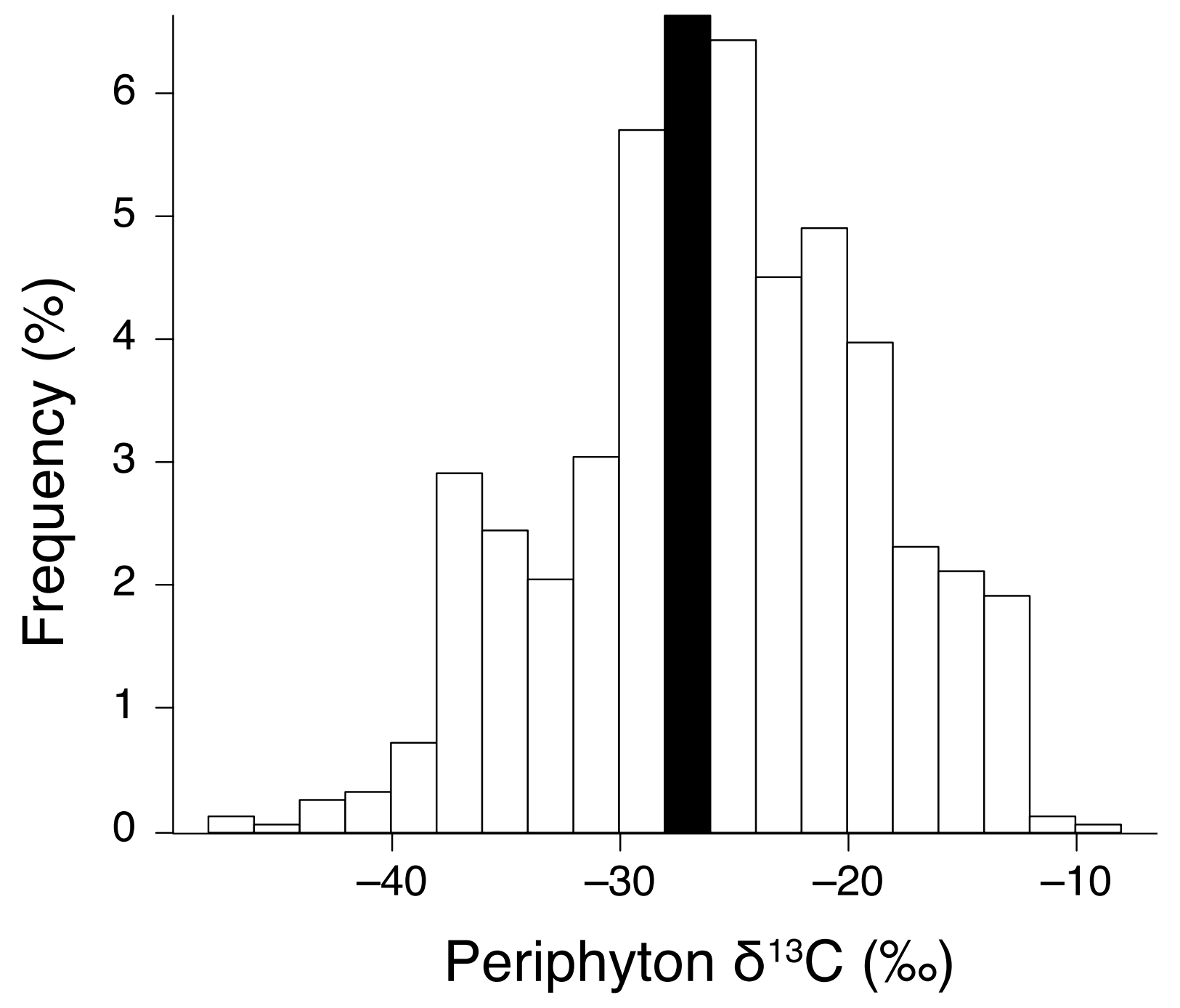

$43 \quad$ Figure 1 
Ishikawa et al. Meta-analyses of lotic periphyton $\delta^{13} \mathrm{C}$

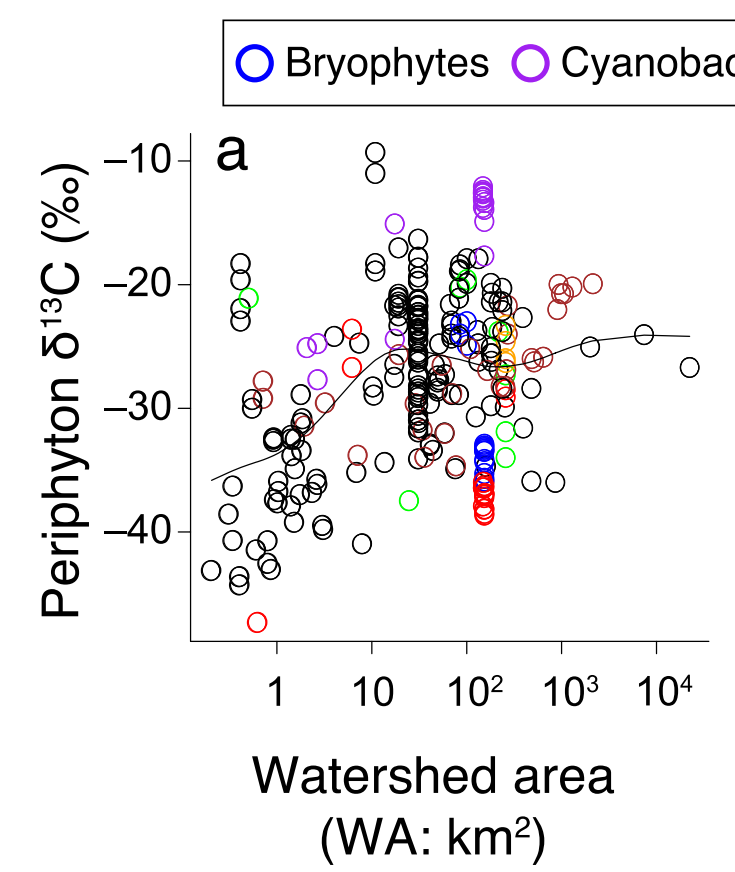
(WA: $\mathrm{km}^{2}$ )

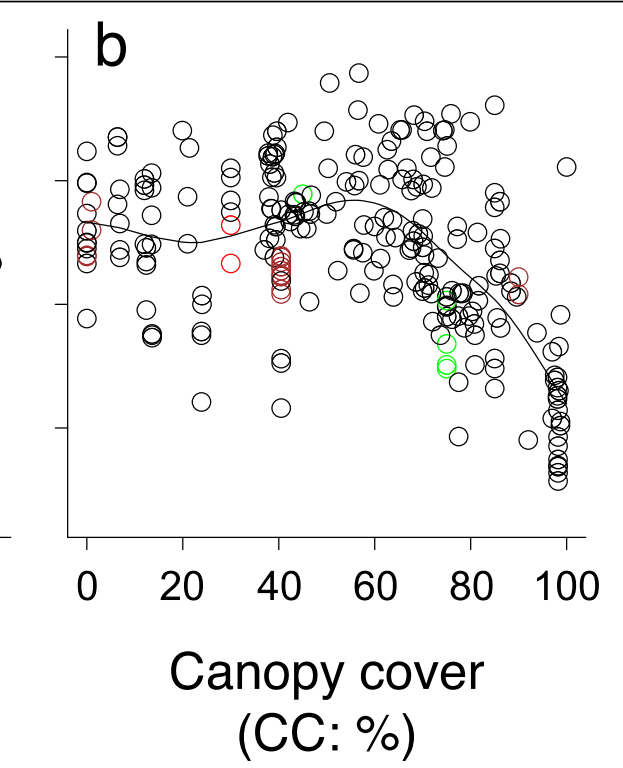

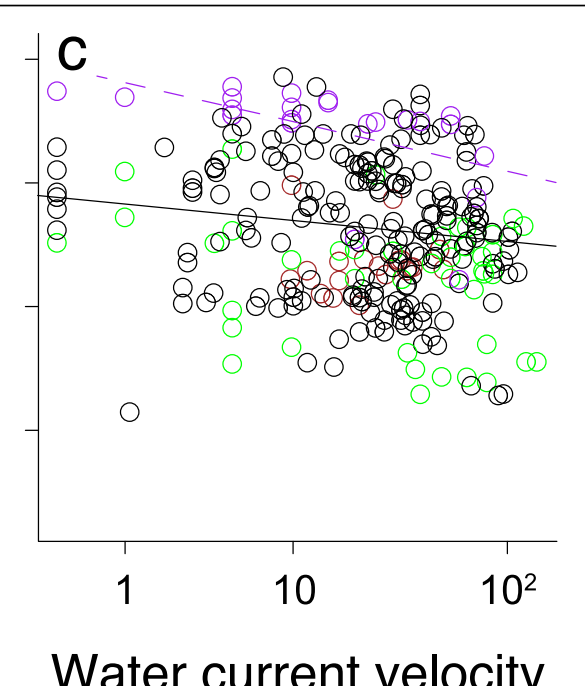

(WCV: $\mathrm{cm} \mathrm{s}^{-1}$ )

\section{O Multiple taxa mixtures}

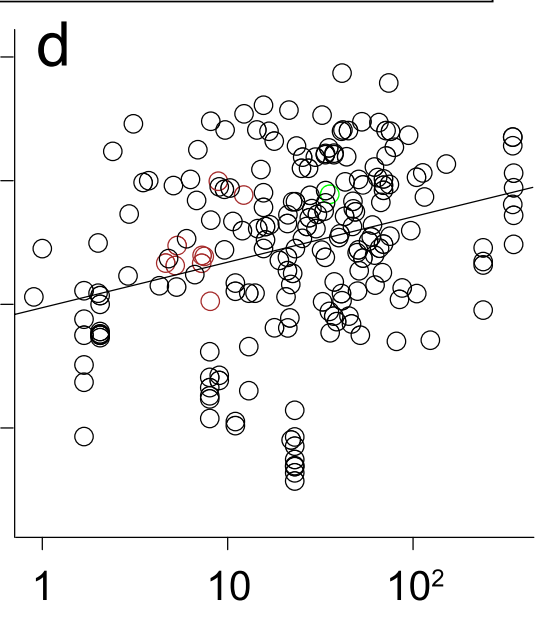

Chlorophyll a density (CHLA: $\mathrm{mg} \mathrm{m}^{-2}$ )

$45 \quad$ Figure 2 
Ishikawa et al. Meta-analyses of lotic periphyton $\delta^{13} \mathrm{C}$

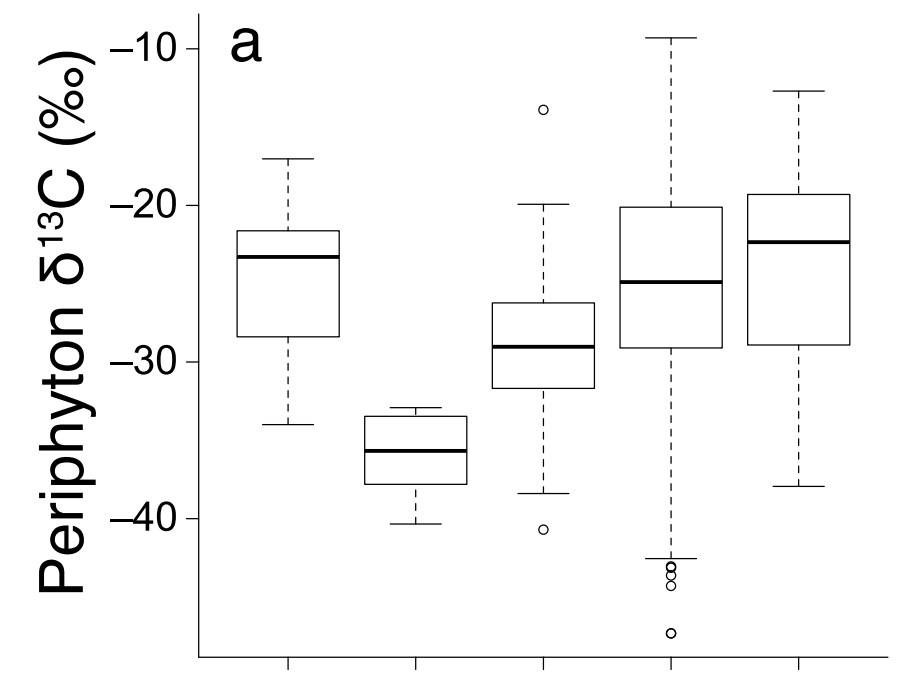

Alpine Arctic Boreal Temperate Tropical

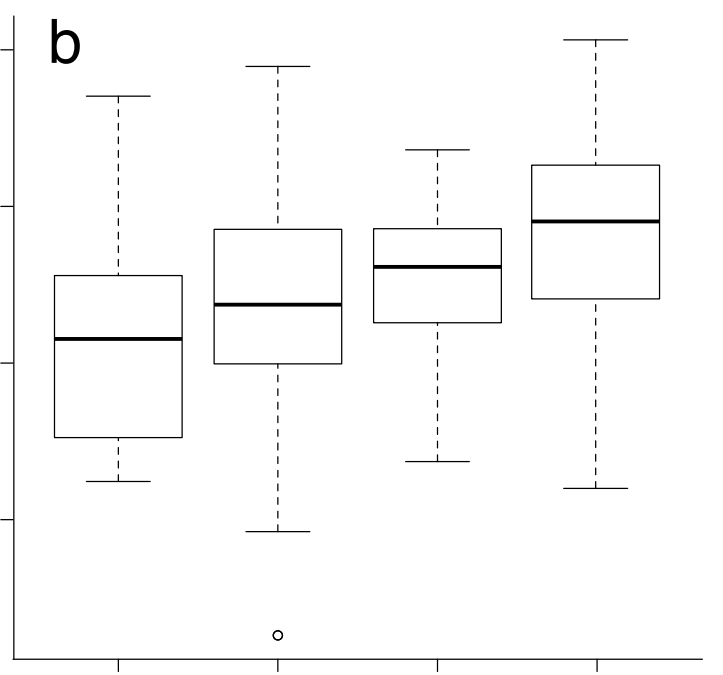

Spring Summer Autumn Winter Season

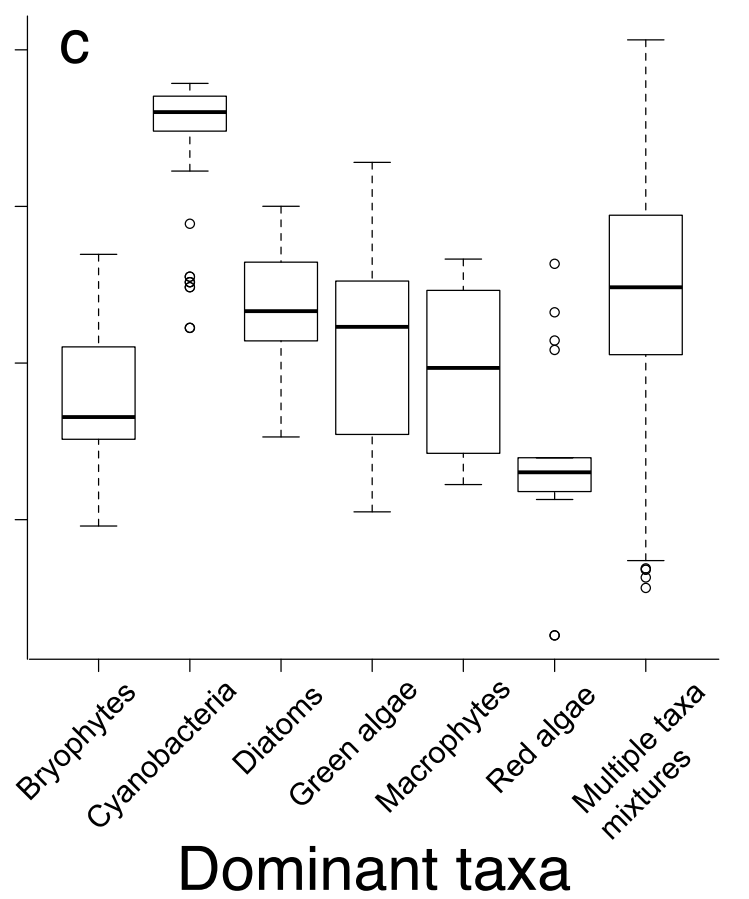

\section{Biome}

Figure 3 
Ishikawa et al. Meta-analyses of lotic periphyton $\delta^{13} \mathrm{C}$

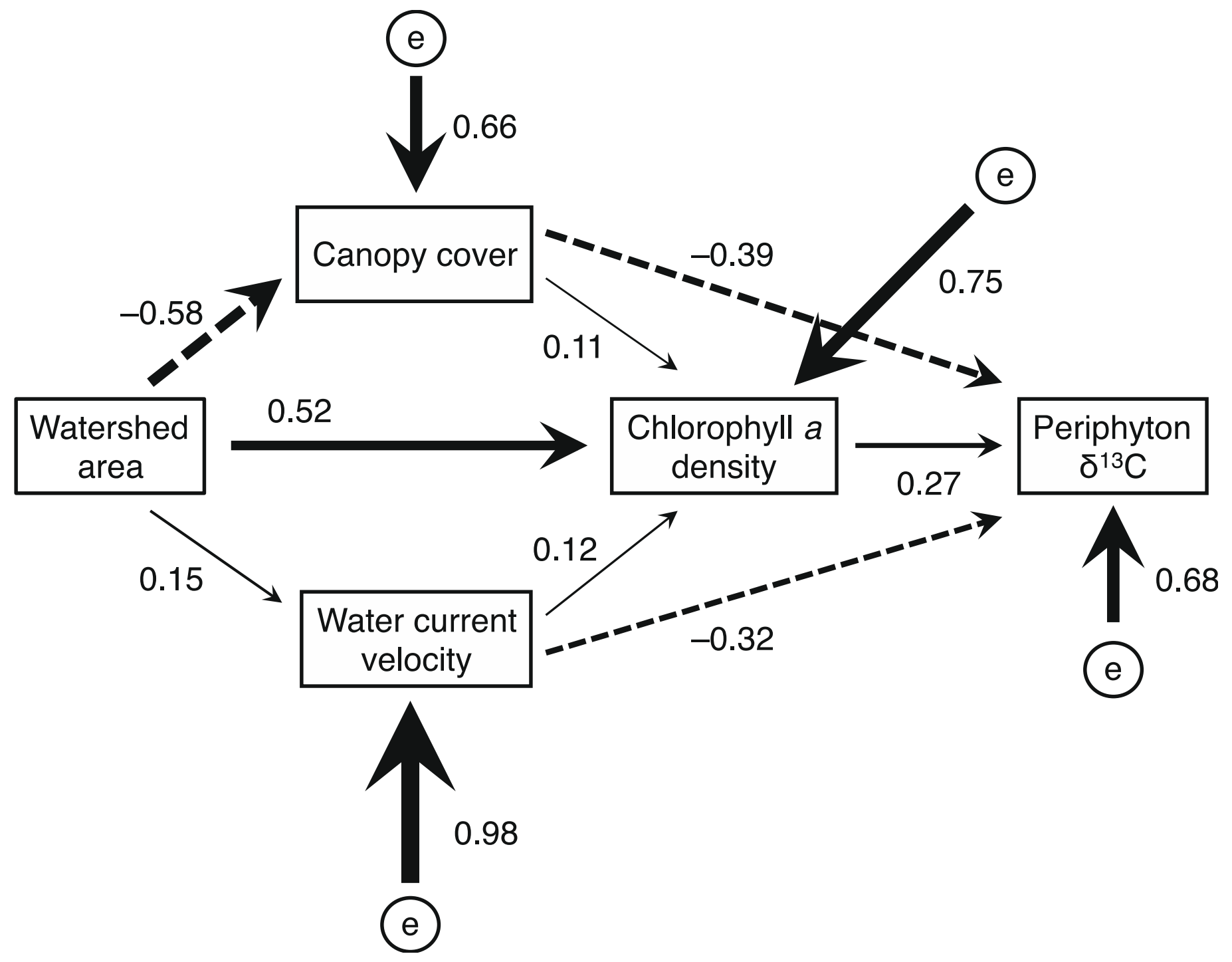

$51 \quad$ Figure 4 
Ishikawa et al. Meta-analyses of lotic periphyton $\delta^{13} \mathrm{C}$

Appendix 1: List of the papers analyzed in this study. "\#” represents paper ID used throughout the Appendices

\begin{tabular}{|c|c|c|c|c|c|c|}
\hline \# & Author(s) & Year & Title & Journal & Volume & Page(s) \\
\hline 1 & $\begin{array}{l}\text { Bergfur J, Johnson RK, Sandin L, } \\
\text { Goedkoop W }\end{array}$ & $(2009)$ & $\begin{array}{l}\text { Effects of nutrient enrichment on } \mathrm{C} \text { and } \mathrm{N} \text { stable isotope ratios of } \\
\text { invertebrates, fish and their food resources in boreal streams }\end{array}$ & Hydrobiologia & 628 & $67-79$ \\
\hline 2 & Bunn SE, Davis PM, Winning M & $(2003)$ & $\begin{array}{l}\text { Sources of organic carbon supporting the food web of an arid zone } \\
\text { floodplain river }\end{array}$ & Freshw Biol & 48 & $619-635$ \\
\hline 3 & $\begin{array}{l}\text { Chessman BC, Westhorpe DP, } \\
\text { Mitrovic SM, Hardwick L }\end{array}$ & $(2009)$ & $\begin{array}{l}\text { Trophic linkages between periphyton and grazing macroinvertebrates in } \\
\text { rivers with different levels of catchment development }\end{array}$ & Hydrobiologia & 625 & $135-150$ \\
\hline 4 & Dekar MP, Magoulick DD, Huxel GR & $(2009)$ & Shifts in the trophic base of intermittent stream food webs & Hydrobiologia & 635 & $263-277$ \\
\hline 5 & $\begin{array}{l}\text { Doi H, Takemon Y, Ohta T, Ishida Y, } \\
\text { Kikuchi E }\end{array}$ & $(2007)$ & $\begin{array}{l}\text { Effects of reach-scale canopy cover on trophic pathways of caddisfly } \\
\text { larvae in a Japanese mountain stream }\end{array}$ & Mar Freshw Res & 58 & $811-817$ \\
\hline 6 & England LE, Rosemond AD & $(2004)$ & $\begin{array}{l}\text { Small reductions in forest cover weaken terrestrial-aquatic linkages in } \\
\text { headwater streams }\end{array}$ & Freshw Biol & 49 & $721-734$ \\
\hline 7 & $\begin{array}{l}\text { Evans-White M, Dodds WK, Gray LJ, } \\
\text { Fritz KM }\end{array}$ & $(2001)$ & $\begin{array}{l}\text { A comparison of the trophic ecology of the crayfishes (Orconectes nais } \\
\text { (Faxon) and Orconectes neglectus (Faxon)) and the central stoneroller } \\
\text { minnow (Campostoma anomalum (Rafinesque)): omnivory in a tallgrass } \\
\text { prairie stream }\end{array}$ & Hydrobiologia & 462 & $131-144$ \\
\hline 8 & Finlay JC & $(2001)$ & $\begin{array}{l}\text { Stable-carbon-isotope ratios of river biota: implications for energy flow } \\
\text { in lotic food webs }\end{array}$ & Ecology & 82 & $1052-1064$ \\
\hline 9 & Finlay JC & $(2004)$ & Patterns and controls of lotic algal stable carbon isotope ratios & $\begin{array}{l}\text { Limnol } \\
\text { Oceanogr }\end{array}$ & 49 & $850-861$ \\
\hline 10 & Finlay JC, Power ME, Cabana G & $(1999)$ & $\begin{array}{l}\text { Effects of water velocity on algal carbon isotope ratios: implications for } \\
\text { river food web studies }\end{array}$ & $\begin{array}{l}\text { Limnol } \\
\text { Oceanogr }\end{array}$ & 44 & $1198-1203$ \\
\hline 11 & France R, Cattaneo A & $(1998)$ & $\begin{array}{l}\delta^{13} \mathrm{C} \text { variability of benthic algae: effects of water colour via modulation } \\
\text { by stream current }\end{array}$ & Freshw Biol & 39 & $617-622$ \\
\hline 12 & $\begin{array}{l}\text { Fuentes Brito E, Moulton TP, De } \\
\text { Souza M, Bunn SE }\end{array}$ & $(2006)$ & $\begin{array}{l}\text { Stable isotope analysis indicates microalgae as the predominant food } \\
\text { source of fauna in a coastal forest stream, south-east Brazil }\end{array}$ & Austral Ecol & 31 & $623-633$ \\
\hline 13 & Füreder L, Welter C, Jackson JK & $(2003)$ & Dietary and stable isotope $\left(\delta^{13} \mathrm{C}, \delta^{15} \mathrm{~N}\right)$ analyses in alpine stream insects & $\begin{array}{l}\text { Int Rev } \\
\text { Hydrobiol }\end{array}$ & 88 & $314-331$ \\
\hline 14 & Godwin CM, Arthur MA, Carrick HJ & $(2009)$ & $\begin{array}{l}\text { Periphyton nutrient status in a temperate stream with mixed land-uses: } \\
\text { implications for watershed nitrogen storage }\end{array}$ & Hydrobiologia & 623 & $141-152$ \\
\hline 15 & Göthe E, Lepori F, Malmqvist B & $(2009)$ & Forestry affects food webs in northern Swedish coastal streams & $\begin{array}{l}\text { Fund Appl } \\
\text { Limnol }\end{array}$ & 175 & $281-294$ \\
\hline
\end{tabular}


Ishikawa et al. Meta-analyses of lotic periphyton $\delta^{13} \mathrm{C}$

\section{Continued}

\begin{tabular}{|c|c|c|c|c|c|c|}
\hline \# & Author(s) & Year & Title & Journal & Volume & Page(s) \\
\hline 16 & Hamilton SK, Sippel, SJ, Bunn SE & $(2005)$ & $\begin{array}{l}\text { Separation of algae from detritus for stable isotope or ecological } \\
\text { stoichiometry studies using density fractionation in colloidal silica }\end{array}$ & $\begin{array}{l}\text { Limnol } \\
\text { Oceanogr } \\
\text { Methods }\end{array}$ & 3 & $149-157$ \\
\hline 17 & $\begin{array}{l}\text { Huryn AD, Riley RH, Young RG, } \\
\text { Arbuckle CJ, Peacock K }\end{array}$ & $(2002)$ & $\begin{array}{l}\text { Natural-abundance stable } \mathrm{C} \text { and } \mathrm{N} \text { isotopes indicate weak } \\
\text { upstream-downstream linkage of food webs in a grassland river }\end{array}$ & $\begin{array}{l}\text { Arch } \\
\text { Hydrobiol }\end{array}$ & 153 & $177-196$ \\
\hline 18 & $\begin{array}{l}\text { Ishikawa NF, Uchida M, Shibata Y, } \\
\text { Tayasu I }\end{array}$ & $(2012)$ & $\begin{array}{l}\text { Natural C-14 provides new data for stream food-web studies: a } \\
\text { comparison with C-13 in multiple stream habitats }\end{array}$ & $\begin{array}{l}\text { Mar Freshw } \\
\text { Res }\end{array}$ & 63 & $210-217$ \\
\hline 19 & Junger M, Planas D & $(1994)$ & $\begin{array}{l}\text { Quantitative use of stable carbon-isotope analysis to determine the trophic } \\
\text { base of invertebrate communities in a boreal forest lotic system }\end{array}$ & $\begin{array}{l}\text { Can J Fish } \\
\text { Aquat Sci }\end{array}$ & 51 & $52-61$ \\
\hline 20 & Lau DCP, Leung KMY, Dudgeon D & $(2009)$ & $\begin{array}{l}\text { Evidence of rapid shifts in the trophic base of lotic predators using } \\
\text { experimental dietary manipulations and assimilation-based analyses }\end{array}$ & Oecologia & 159 & $767-776$ \\
\hline 21 & Lau DCP, Leung KMY, Dudgeon D & $(2009)$ & $\begin{array}{l}\text { What does stable isotope analysis reveal about trophic relationships and } \\
\text { the relative importance of allochthonous and autochthonous resources in } \\
\text { tropical streams? A synthetic study from Hong Kong }\end{array}$ & Freshw Biol & 54 & $127-141$ \\
\hline 22 & Li AOY, Dudgeon D & $(2008)$ & $\begin{array}{l}\text { Food resources of shredders and other benthic macroinvertebrates in } \\
\text { relation to shading conditions in tropical Hong Kong streams }\end{array}$ & Freshw Biol & 53 & $2011-2025$ \\
\hline 23 & $\begin{array}{l}\text { Manetta GI, Benedito-Cecilio E, } \\
\text { Martinelli M }\end{array}$ & $(2003)$ & $\begin{array}{l}\text { Carbon sources and trophic position of the main species of fishes of Baía } \\
\text { River, Paraná River floodplain, Brazil }\end{array}$ & Braz J Biol & 63 & $283-290$ \\
\hline 24 & McCutchan JH, Lewis WM & $(2001)$ & Seasonal variation in stable isotope ratios of stream algae & $\begin{array}{l}\text { Verh Internat } \\
\text { Verein Limnol }\end{array}$ & 27 & $3304-3307$ \\
\hline 25 & Parkyn SM, Collier KJ, Hicks BJ & $(2001)$ & $\begin{array}{l}\text { New Zealand stream crayfish: functional omnivores but trophic } \\
\text { predators? }\end{array}$ & Freshw Biol & 46 & $641-652$ \\
\hline 26 & Pereira AL, Benedito E, Sakuragui CM & $(2007)$ & $\begin{array}{l}\text { Spatial variation in the stable isotopes of }{ }^{13} \mathrm{C} \text { and }{ }^{15} \mathrm{~N} \text { and trophic position } \\
\text { of Leporinus friderici (Characiformes, Anostomidae) in Corumbá } \\
\text { Reservoir, Brazil }\end{array}$ & $\begin{array}{l}\text { An Acad Bras } \\
\text { Cienc }\end{array}$ & 79 & $41-49$ \\
\hline 27 & Perry RW, Bradford MJ, Grout JA & $(2003)$ & $\begin{array}{l}\text { Effects of disturbance on contribution of energy sources to growth of } \\
\text { juvenile chinook salmon (Oncorhynchus tshawytscha) in boreal streams }\end{array}$ & $\begin{array}{l}\text { Can J Fish } \\
\text { Aquat Sci }\end{array}$ & 60 & $390-400$ \\
\hline 28 & Primavera $\mathrm{JH}$ & $(1996)$ & $\begin{array}{l}\text { Stable carbon and nitrogen isotope ratios of Penaeid juveniles and } \\
\text { primary producers in a riverine mangrove in Guimaras, Philippines }\end{array}$ & B Mar Sci & 58 & $675-683$ \\
\hline 29 & Rasmussen JB, Trudeau V & $(2007)$ & $\begin{array}{l}\text { Influence of velocity and chlorophyll standing stock on periphyton } \delta^{13} \mathrm{C} \\
\text { and } \delta^{15} \mathrm{~N} \text { in the Ste. Marguerite River system, Quebec }\end{array}$ & $\begin{array}{l}\text { Can J Fish } \\
\text { Aquat Sci }\end{array}$ & 64 & $1370-1381$ \\
\hline 30 & Rasmussen JB, Trudeau V & $(2010)$ & $\begin{array}{l}\text { How well are velocity effects on } \partial^{13} \mathrm{C} \text { signatures transmitted up the food } \\
\text { web from algae to fish? }\end{array}$ & Freshw Biol & 55 & $1303-1314$ \\
\hline
\end{tabular}


Ishikawa et al. Meta-analyses of lotic periphyton $\delta^{13} \mathrm{C}$

\section{Continued}

\begin{tabular}{|c|c|c|c|c|c|c|}
\hline$\#$ & Author(s) & Year & Title & Journal & Volume & Page(s) \\
\hline 31 & $\begin{array}{l}\text { Rasmussen JB, Trudeau V, Morinville } \\
\text { G }\end{array}$ & $(2009)$ & $\begin{array}{l}\text { Estimating the scale of fish feeding movements in rivers using } \delta^{13} \mathrm{C} \\
\text { signature gradients }\end{array}$ & J Anim Ecol & 78 & $674-685$ \\
\hline 32 & $\begin{array}{l}\text { Robinson CT, Schmid D, Svoboda M, } \\
\text { Bernasconi SM }\end{array}$ & (2008) & $\begin{array}{l}\text { Functional measures and food webs of high elevation springs in the Swiss } \\
\text { alps }\end{array}$ & Aquat Sci & 70 & $432-445$ \\
\hline 33 & $\begin{array}{l}\text { Singer GA, Panzenböck M, } \\
\text { Weigelhofer G, Marchesani C, } \\
\text { Waringer J, Wanek W, Battin TJ }\end{array}$ & $(2005)$ & $\begin{array}{l}\text { Flow history explains temporal and spatial variation of carbon } \\
\text { fractionation in stream periphyton }\end{array}$ & $\begin{array}{l}\text { Limnol } \\
\text { Oceanogr }\end{array}$ & 50 & $706-712$ \\
\hline 34 & Spencer CN, Gabel KO, Hauer FR & $(2003)$ & $\begin{array}{l}\text { Wildfire effects on stream food webs and nutrient dynamics in Glacier } \\
\text { National Park, USA }\end{array}$ & $\begin{array}{l}\text { Forest Ecol } \\
\text { Manag }\end{array}$ & 178 & $141-153$ \\
\hline 35 & $\begin{array}{l}\text { Thorp JH, Delong MD, Greenwood } \\
\text { KA, Casper AF }\end{array}$ & (1998) & $\begin{array}{l}\text { Isotopic analysis of three food web theories in constricted and floodplain } \\
\text { regions of a large river }\end{array}$ & Oecologia & 117 & $551-563$ \\
\hline 36 & $\begin{array}{l}\text { Trimmer M, Hildrew AG, Jackson MC, } \\
\text { Pretty JL, Grey J }\end{array}$ & (2009) & $\begin{array}{l}\text { Evidence for the role of methane-derived carbon in a free-flowing, } \\
\text { lowland river food web }\end{array}$ & $\begin{array}{l}\text { Limnol } \\
\text { Oceanogr }\end{array}$ & 54 & $1541-1547$ \\
\hline 37 & $\begin{array}{l}\text { Verburg P, Kilham SS, Pringle CM, } \\
\text { Lips KR, Drake DL }\end{array}$ & $(2007)$ & $\begin{array}{l}\text { A stable isotope study of a neotropical stream food web prior to the } \\
\text { extirpation of its large amphibian community }\end{array}$ & J Trop Ecol & 23 & $643-651$ \\
\hline 38 & Walters AW, Barnes RT, Post DM & (2009) & $\begin{array}{l}\text { Anadromous alewives (Alosa pseudoharengus) contribute marine-derived } \\
\text { nutrients to coastal stream food webs }\end{array}$ & $\begin{array}{l}\text { Can J Fish } \\
\text { Aquat Sci }\end{array}$ & 66 & $439-448$ \\
\hline 39 & $\begin{array}{l}\text { Watanabe K, Monaghan MT, Takemon } \\
\text { Y, Omura T }\end{array}$ & $(2008)$ & $\begin{array}{l}\text { Biodilution of heavy metals in a stream macroinvertebrate food web: } \\
\text { Evidence from stable isotope analysis }\end{array}$ & $\begin{array}{l}\text { Sci Total } \\
\text { Environ }\end{array}$ & 394 & $57-67$ \\
\hline 40 & $\begin{array}{l}\text { Winemiller KO, Hoeinghaus DJ, Pease } \\
\text { AA, Esselman PC, Honeycutt RL, } \\
\text { Gbanaador D, Carrera, Payne J }\end{array}$ & (2011) & $\begin{array}{l}\text { Stable isotope analysis reveals food web structure and watershed impacts } \\
\text { along the fluvial gradient of a Mesoamerican coastal river }\end{array}$ & River Res Appl & 27 & $791-803$ \\
\hline 41 & $\begin{array}{l}\text { Zah R, Burgherr P, Bernasconi SM, } \\
\text { Uehlinger U }\end{array}$ & $(2001)$ & $\begin{array}{l}\text { Stable isotope analysis of macroinvertebrates and their food sources in a } \\
\text { glacier stream }\end{array}$ & Freshw Biol & 46 & $871-882$ \\
\hline 42 & Zeug SC, Winemiller KO & (2008) & $\begin{array}{l}\text { Evidence supporting the importance of terrestrial carbon in a large-river } \\
\text { food web }\end{array}$ & Ecology & 89 & $1733-1743$ \\
\hline 43 & Unpublished data from JC Finlay & - & - & - & - & - \\
\hline 44 & Unpublished data from H Doi & - & - & - & - & - \\
\hline \multicolumn{7}{|c|}{ Total } \\
\hline & shed \& 2 unpublished sources & & & & & \\
\hline
\end{tabular}


Ishikawa et al. Meta-analyses of lotic periphyton $\delta^{13} \mathrm{C}$

Appendix 2: Study site, Sample size, periphyton $\delta^{13} \mathrm{C}$, and explanatory (numerical) variables collected from each paper. When a paper has multiple data, mean and \pm 1 SD are shown

\begin{tabular}{|c|c|c|c|c|c|c|c|}
\hline \# & Site & $\mathrm{n}$ & $\begin{array}{l}\text { Periphyton } \delta^{13} \mathrm{C} \\
(\%)\end{array}$ & $\begin{array}{l}\text { Watershed area } \\
\left(\mathrm{km}^{2}\right)\end{array}$ & Canopy cover $(\%)$ & $\begin{array}{l}\text { Water current } \\
\text { velocity }\left(\mathrm{cm} \mathrm{s}^{-1}\right)\end{array}$ & $\begin{array}{l}\text { Chlorophyll } a \\
\text { density }\left(\mathrm{mg} \mathrm{m}^{-2}\right)\end{array}$ \\
\hline 1 & Algangsan \& others & 6 & $-31.6 \pm 3.4$ & $299.8 \pm 290.7$ & & & \\
\hline 2 & Mayfield \& others & 13 & $-19.6 \pm 3.0$ & & & & \\
\hline 3 & Murrumbidgee River & 43 & $-26.6 \pm 1.6$ & & & & \\
\hline 4 & Arkansas River & 15 & $-23.4 \pm 3.5$ & $163.0 \pm 64.5$ & & & \\
\hline 5 & Kamo River & 8 & $-17.4 \pm 2.0$ & & $48.6 \pm 22.6$ & $64.9 \pm 9.5$ & $52.5 \pm 14.2$ \\
\hline 6 & Chattahoochee River & 2 & $-24.5 \pm 0.4$ & $5.5 \pm 2.3$ & $79.3 \pm 3.0$ & & \\
\hline 7 & Kings Creek & 4 & $-14.4 \pm 4.9$ & $10.6 \pm 0.0$ & & & \\
\hline 8 & Eel River & 6 & $-32.3 \pm 5.1$ & $79.4 \pm 148.3$ & $51.0 \pm 46.6$ & & \\
\hline 9 & Eel River & 33 & $-34.4 \pm 6.9$ & $971.1 \pm 4001.7$ & $77.6 \pm 35.8$ & & $15.2 \pm 6.6$ \\
\hline 10 & Eel River & 6 & $-23.3 \pm 3.7$ & $108.9 \pm 74.8$ & $44.0 \pm 35.6$ & & $21.9 \pm 10.7$ \\
\hline 11 & $\begin{array}{l}\text { Streams in Laurentian } \\
\text { mountains }\end{array}$ & 15 & $-28.8 \pm 4.1$ & & $40.5 \pm 0.0$ & $21.0 \pm 11.9$ & \\
\hline 12 & Córrego da Andorinha & 5 & $-22.5 \pm 2.8$ & & $27.8 \pm 6.8$ & & \\
\hline 13 & River Inn & 2 & $-26.3 \pm 2.1$ & $50.0 \pm 0.0$ & & & \\
\hline 14 & Spring Creek & 20 & $-21.9 \pm 4.2$ & & $25.9 \pm 30.4$ & & $203.3 \pm 141.8$ \\
\hline 15 & Swedish streams & 14 & $-33.1 \pm 3.3$ & $1.1 \pm 0.5$ & $45.0 \pm 30.1$ & & $1.9 \pm 0.2$ \\
\hline
\end{tabular}


Ishikawa et al. Meta-analyses of lotic periphyton $\delta^{13} \mathrm{C}$

Continued

\begin{tabular}{|c|c|c|c|c|c|c|c|c|}
\hline \# & Site & $\mathrm{n}$ & $\begin{array}{l}\text { Periphyton } \delta^{13} \mathrm{C} \\
(\%)\end{array}$ & $\begin{array}{l}\text { Watershed area } \\
\left(\mathrm{km}^{2}\right)\end{array}$ & Canopy cover $(\%)$ & $\begin{array}{l}\text { Water current } \\
\text { velocity }\left(\mathrm{cm} \mathrm{s}^{-1}\right)\end{array}$ & $\begin{array}{l}\text { Chloro } \\
\text { density }\end{array}$ & $\begin{array}{l}\text { phyll } a \\
\left(\mathrm{mg} \mathrm{m}^{-2}\right)\end{array}$ \\
\hline 16 & $\begin{array}{l}\text { Several sites in } \\
\text { Queensland }\end{array}$ & 20 & $-25.5 \pm 4.7$ & & & & & \\
\hline 17 & Taieri River & 22 & $-24.2 \pm 4.3$ & $173.1 \pm 78.5$ & & & & \\
\hline 18 & Seri River & 48 & $-24.5 \pm 3.9$ & 30 & $56.1 \pm 16.0$ & $37.3 \pm 18.0$ & 53.5 & \pm 29.7 \\
\hline 19 & Montmorency River & 6 & $-25.5 \pm 2.9$ & $90.6 \pm 135.1$ & $40.3 \pm 40.6$ & & & \\
\hline 20 & Pak Ngau Shek Stream & 1 & -14.2 & & & & & \\
\hline 21 & $\begin{array}{l}\text { Several streams in Hong } \\
\text { Kong }\end{array}$ & 4 & $-22.7 \pm 2.3$ & & $50.0 \pm 23.1$ & & & \\
\hline 22 & Hong Kong stream & 9 & $-18.0 \pm 4.3$ & & & $37.8 \pm 9.7$ & & \\
\hline 23 & Parana River & 1 & -28.6 & & & & & 5.3 \\
\hline 24 & St. Vrain Creek & 14 & $-19.1 \pm 2.1$ & & & & & \\
\hline 25 & $\begin{array}{l}\text { Mangaotama Stream \& } \\
\text { Firewood Creek }\end{array}$ & 1 & -21.1 & 0.5 & 45.0 & & & 35.5 \\
\hline 26 & Corumba River & 1 & -21.6 & 65.0 & & & & 6.8 \\
\hline 27 & Yukon River & 6 & $-32.4 \pm 3.2$ & $195.2 \pm 214.2$ & & & & \\
\hline 28 & Sibunag River \& others & 5 & $-19.8 \pm 3.9$ & & & & & \\
\hline 29 & St. Marguerite River & 9 & $-25.4 \pm 3.0$ & & $0.0 \pm 0.0$ & $32.0 \pm 13.2$ & 7.4 & \pm 2.3 \\
\hline 30 & $\begin{array}{l}\text { St. Marguerite River \& } \\
\text { others }\end{array}$ & 15 & $-29.8 \pm 0.7$ & & & $21.0 \pm 17.0$ & & \\
\hline
\end{tabular}


Ishikawa et al. Meta-analyses of lotic periphyton $\delta^{13} \mathrm{C}$

Continued

\begin{tabular}{|c|c|c|c|c|c|c|c|}
\hline$\#$ & Site & $\mathrm{n}$ & $\begin{array}{l}\text { Periphyton } \delta^{13} \mathrm{C} \\
(\%)\end{array}$ & $\begin{array}{l}\text { Watershed area } \\
\left(\mathrm{km}^{2}\right)\end{array}$ & Canopy cover $(\%)$ & $\begin{array}{l}\text { Water current } \\
\text { velocity }\left(\mathrm{cm} \mathrm{s}^{-1}\right)\end{array}$ & $\begin{array}{l}\text { Chlorophyll } a \\
\text { density }\left(\mathrm{mg} \mathrm{m}^{-2}\right)\end{array}$ \\
\hline 31 & $\begin{array}{l}\text { St. Marguerite River \& } \\
\text { others }\end{array}$ & 25 & $-27.0 \pm 4.6$ & $406.3 \pm 525.8$ & & & \\
\hline 32 & $\begin{array}{l}\text { Several springs in } \\
\text { Switzerland }\end{array}$ & 6 & $-30.6 \pm 1.8$ & & & & \\
\hline 33 & Kleine Erlauf & 3 & $-31.8 \pm 1.9$ & $40.0 \pm 0.0$ & & $44.7 \pm 3.4$ & $96.5 \pm 23.7$ \\
\hline 34 & $\begin{array}{l}\text { Akokala \& Bowman } \\
\text { creeks }\end{array}$ & 1 & -21.4 & & & & \\
\hline 35 & Ohio River & 3 & $-21.9 \pm 1.1$ & & & & \\
\hline 36 & River Lambourn & 4 & $-35.8 \pm 1.4$ & & & & \\
\hline 37 & Rio Guabal & 8 & $-31.7 \pm 2.4$ & & $75.0 \pm 0.0$ & & \\
\hline 38 & $\begin{array}{l}\text { Several streams in } \\
\text { Connecticut }\end{array}$ & 34 & $-28.8 \pm 2.4$ & & & & \\
\hline 39 & Several streams in Japan & 4 & $-21.7 \pm 2.7$ & & $37.5 \pm 47.9$ & & \\
\hline 40 & Monkey River & 9 & $-25.2 \pm 6.7$ & & & & \\
\hline 41 & Roseg River & 22 & $-22.9 \pm 3.0$ & $31.8 \pm 24.8$ & & & \\
\hline 42 & Brazos River & 3 & $-21.1 \pm 4.0$ & & $0.0 \pm 0.0$ & & $2.3 \pm 1.3$ \\
\hline 43 & Several streams in the US & 229 & $-26.1 \pm 8.3$ & $127.7 \pm 50.2$ & & $40.2 \pm 35.3$ & \\
\hline 44 & Kurama River & 60 & $-21.8 \pm 5.7$ & & $65.5 \pm 12.1$ & $18.4 \pm 12.1$ & $26.5 \pm 20.8$ \\
\hline \multicolumn{8}{|c|}{ Total } \\
\hline & & 765 & $-25.7 \pm 6.8$ & $272.2 \pm 1569.5$ & $54.8 \pm 28.6$ & $\pm \quad 27.2$ & $47.5 \pm 72.3$ \\
\hline
\end{tabular}


Ishikawa et al. Meta-analyses of lotic periphyton $\delta^{13} \mathrm{C}$

Appendix 3: Explanatory (categorical) variables and topographical information (altitude, slope, and width of site) collected from each paper.

When a paper has multiple data, all attributes are listed and/or mean and $\pm 1 \mathrm{SD}$ are shown

\begin{tabular}{|c|c|c|c|c|c|c|}
\hline \# & Biome & Season & Dominant taxa & Altitude (m a.s.1.) & Slope $(\%)$ & Width (m) \\
\hline 1 & Boreal & Autumn & Multiple taxa mixtures & $66.6 \pm 68.7$ & & $7.8 \pm 2.6$ \\
\hline 3 & Temperate & Annual & Multiple taxa mixtures & & & \\
\hline 4 & Temperate & $\begin{array}{l}\text { Spring; Summer; } \\
\text { Winter }\end{array}$ & Multiple taxa mixtures & & & $28.5 \pm 3.5$ \\
\hline 7 & Temperate & Summer; Winter & Multiple taxa mixtures & & & \\
\hline 8 & Temperate & Summer & Multiple taxa mixtures & & & \\
\hline 9 & Temperate & Spring; Summer & Multiple taxa mixtures & & & \\
\hline 10 & Temperate & Summer & Multiple taxa mixtures & & & \\
\hline 11 & Boreal & Summer & Diatoms & & & \\
\hline
\end{tabular}


Ishikawa et al. Meta-analyses of lotic periphyton $\delta^{13} \mathrm{C}$

\section{Continued}

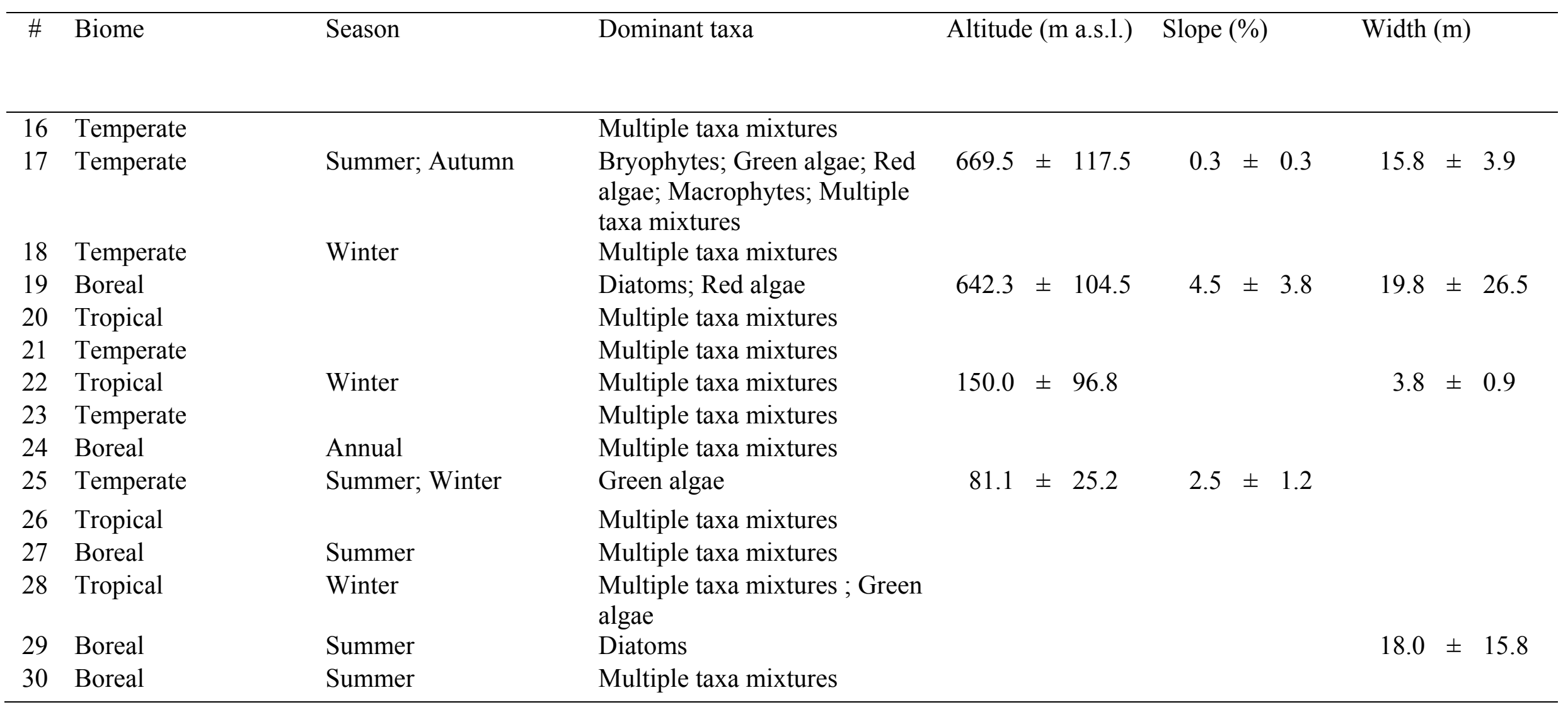


Ishikawa et al. Meta-analyses of lotic periphyton $\delta^{13} \mathrm{C}$

\section{Continued}

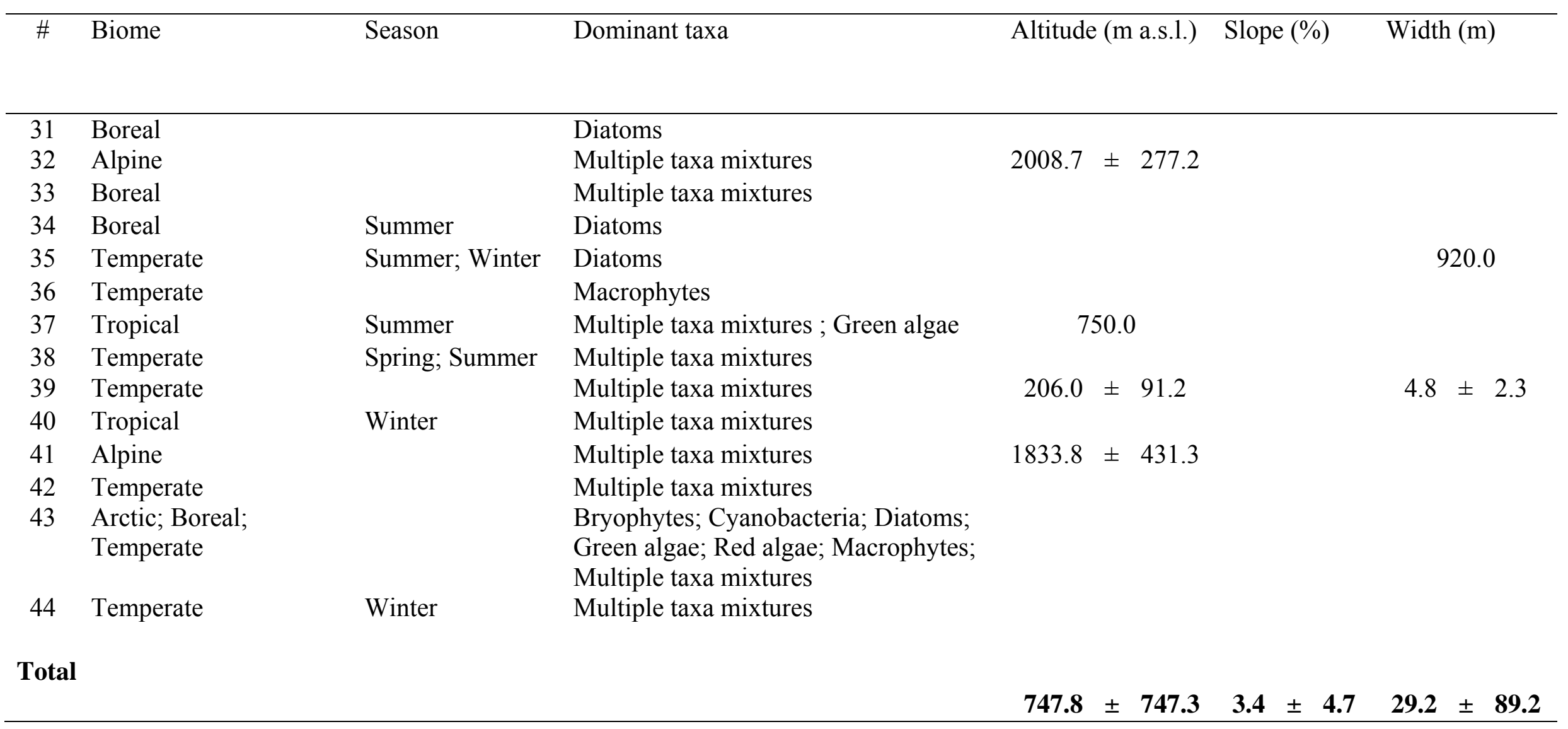


Ishikawa et al. Meta-analyses of lotic periphyton $\delta^{13} \mathrm{C}$

Appendix 4: Physicochemical (nutrient concentration, water temperature, $\mathrm{pH}$, geology, and vegetation of site) information collected from each paper. When a paper has multiple data, all attributes are listed and/or mean and $\pm 1 \mathrm{SD}$ are shown

\begin{tabular}{|c|c|c|c|c|c|c|c|c|}
\hline \# & $\begin{array}{l}\text { Phosphorous (ng } \\
\mathrm{PO}_{4}{ }^{3-} \mathrm{L}^{-1} \text { ) }\end{array}$ & $\begin{array}{l}\text { Nitrate+Nitrite } \\
\left(\left(\mu \mathrm{NO}_{2}^{-}+\mu \mathrm{g}\right.\right. \\
\left.\left.\mathrm{NO}_{3}^{-}\right) \mathrm{L}^{-1}\right)\end{array}$ & $\begin{array}{l}\text { Ammonium } \\
\left(\mathrm{ng} \mathrm{NH}_{4}^{+} \mathrm{L}^{-1}\right)\end{array}$ & $\begin{array}{l}\text { Water } \\
\text { temperature } \\
\left({ }^{\circ} \mathrm{C}\right)\end{array}$ & $\mathrm{pH}$ & & Geology & Vegetation \\
\hline 1 & & $0.488 \pm 0.705$ & & & 7.1 & \pm 0.5 & & Coniferous forest \\
\hline \multicolumn{9}{|l|}{2} \\
\hline 3 & $276.3 \pm 65.0$ & $0.559 \pm 0.247$ & $399.9 \pm 112.6$ & & & & & \\
\hline 4 & & $0.010 \pm 0.000$ & & & & & & $\begin{array}{l}\text { Upland hardwood } \\
\text { species mixed with } \\
\text { shortleaf pine }\end{array}$ \\
\hline 5 & & & & & & & & Oak; Bamboo \\
\hline \multicolumn{9}{|r|}{ 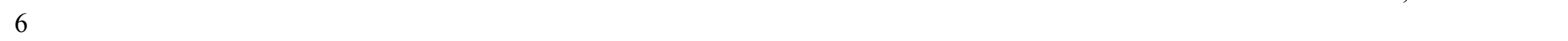 } \\
\hline 7 & & & & & & & & Grasses; Shrubs \\
\hline \multicolumn{9}{|l|}{8} \\
\hline \multicolumn{9}{|l|}{9} \\
\hline 10 & & & & $20.9 \pm 3.3$ & 8.4 & \pm 0.3 & & \\
\hline 11 & & & & 25.0 & & 6.9 & & \\
\hline 12 & & & & & & 6.6 & Granite & \\
\hline \multicolumn{9}{|l|}{13} \\
\hline 14 & $4.8 \pm 1.6$ & $2.590 \pm 1.497$ & & $9.4 \pm 1.0$ & 7.7 & \pm 0.6 & & $\begin{array}{l}\text { Several vegetations } \\
\text { included }\end{array}$ \\
\hline 15 & & & & & 6.7 & \pm 0.5 & Granite; Diabase & $\begin{array}{l}\text { Picea abies; Alnus } \\
\text { incana }\end{array}$ \\
\hline
\end{tabular}


Ishikawa et al. Meta-analyses of lotic periphyton $\delta^{13} \mathrm{C}$

\section{Continued}

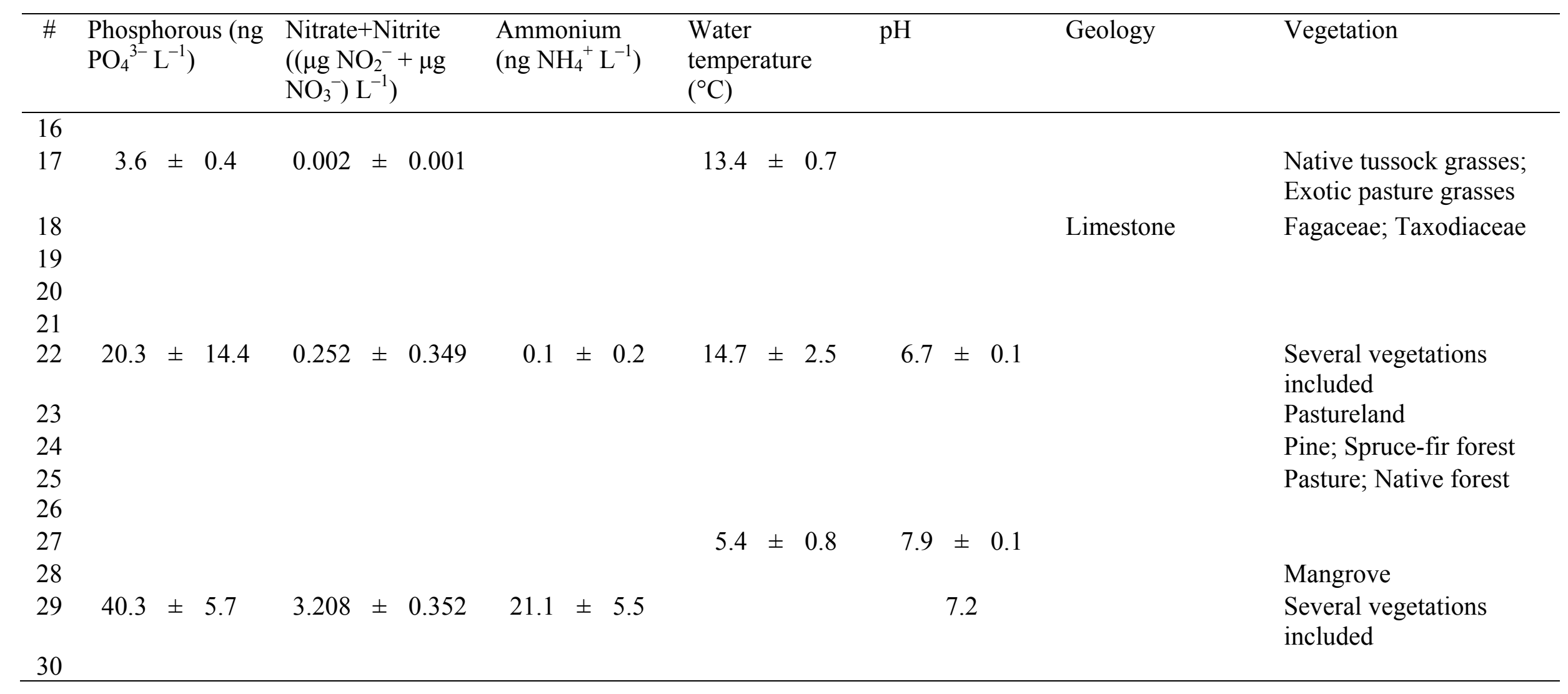


Ishikawa et al. Meta-analyses of lotic periphyton $\delta^{13} \mathrm{C}$

Continued

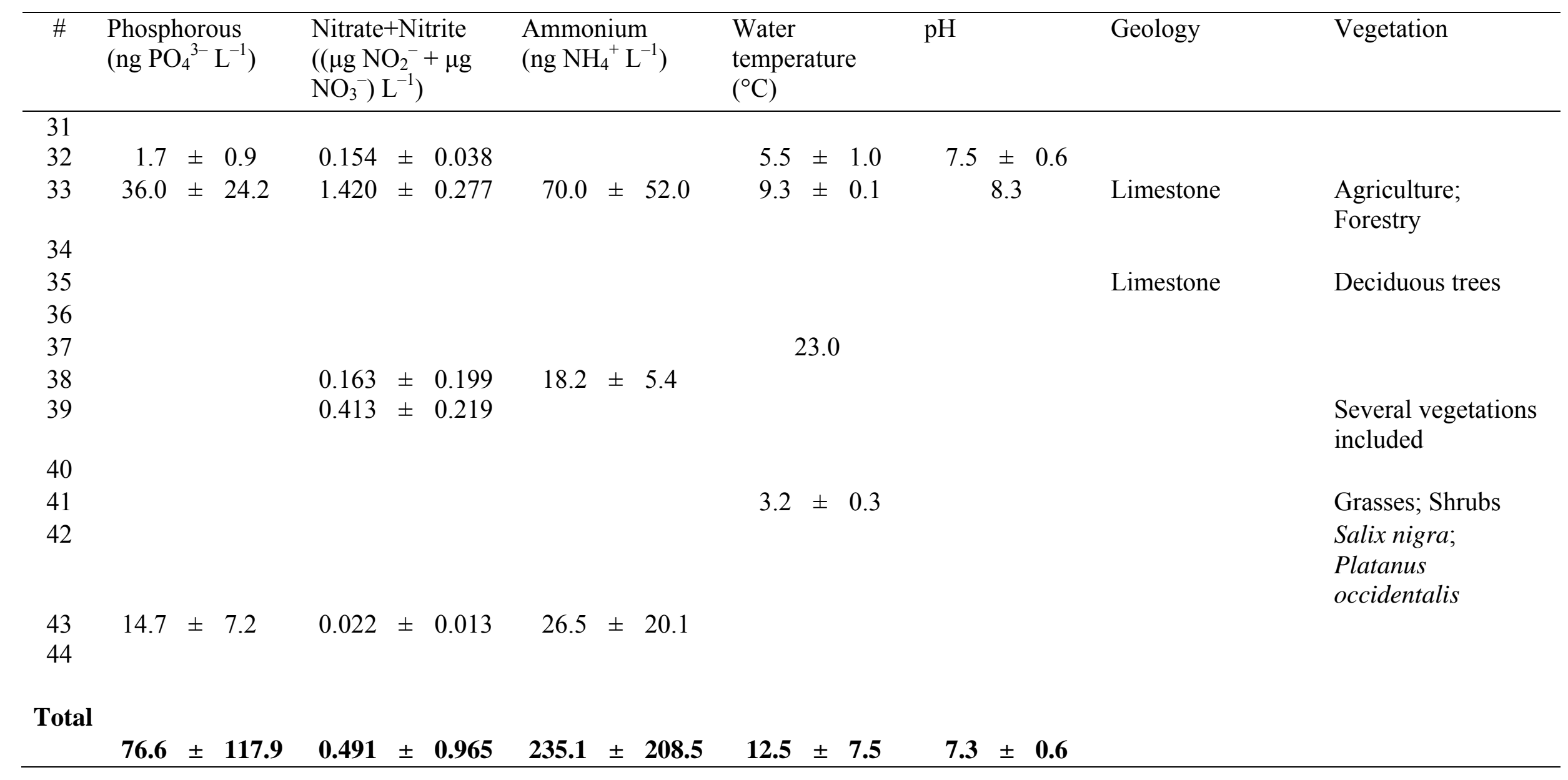


Ishikawa et al. Meta-analyses of lotic periphyton $\delta^{13} \mathrm{C}$

Appendix 5: Distribution of data among biomes, seasons and dominant taxa
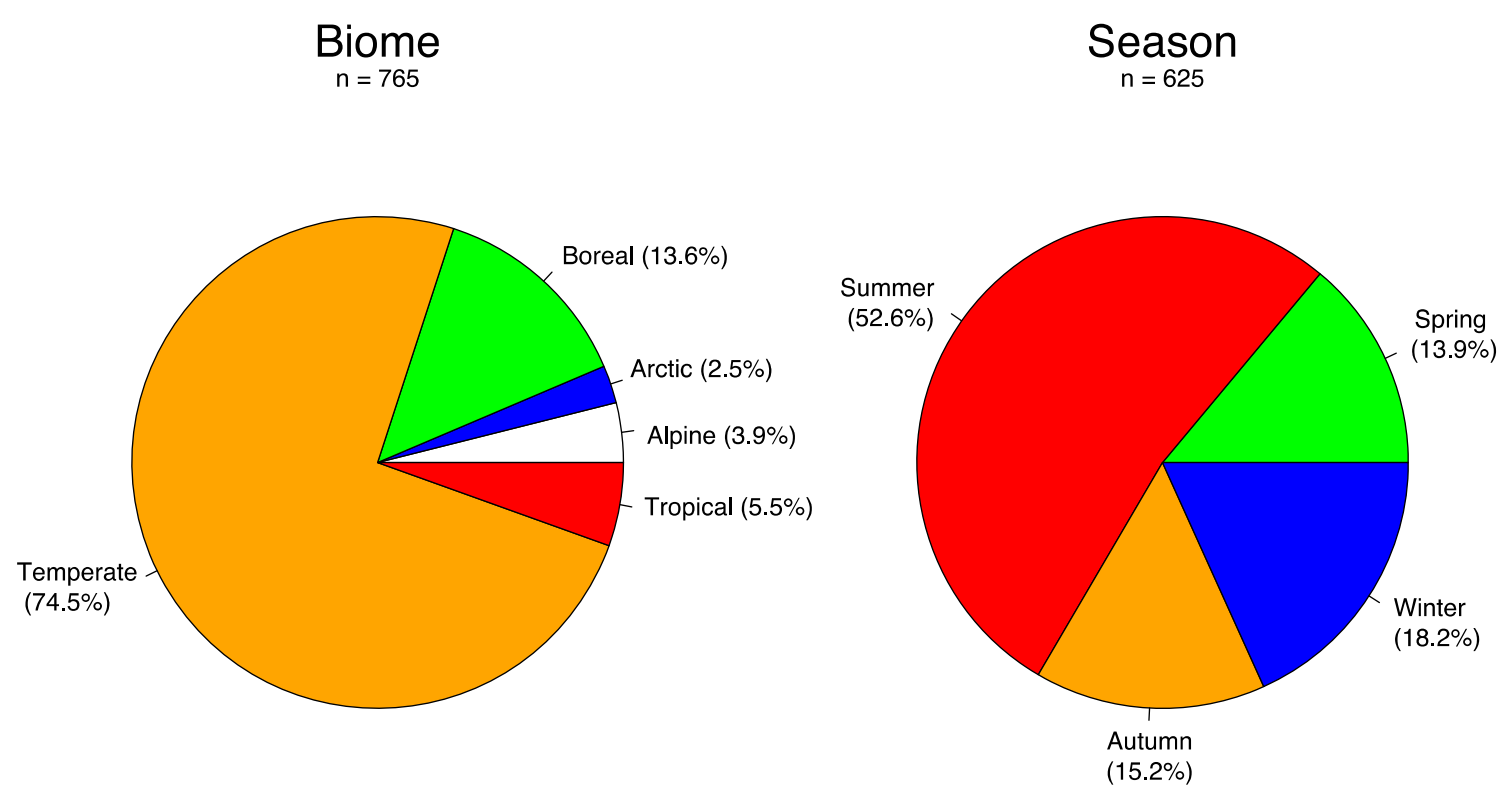

\section{Dominant taxa \\ $n=765$}

Macrophytes

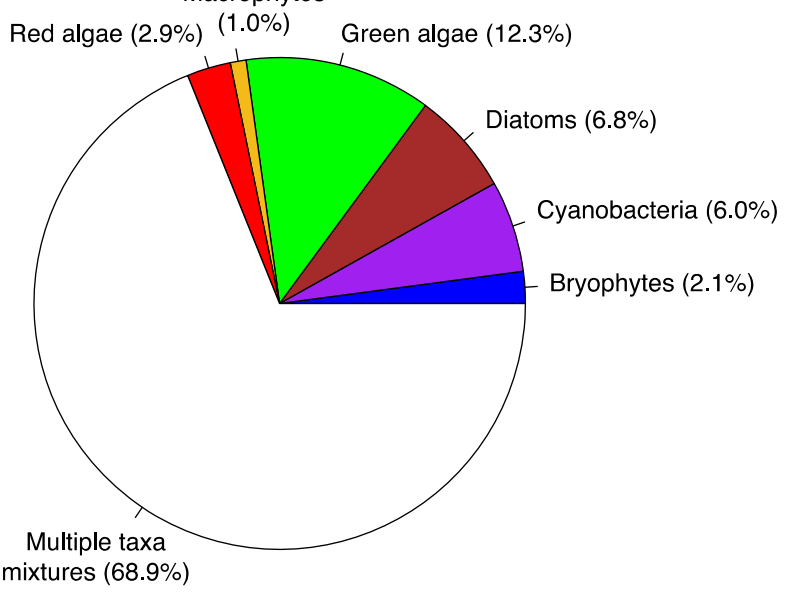


Ishikawa et al. Meta-analyses of lotic periphyton $\delta^{13} \mathrm{C}$

1 Appendix 6: Histograms, scatter plots, and correlation matrices of variables used for structural

2 equation modeling to explain periphyton $\delta^{13} \mathrm{C}$. WA, CC, WCV, and CHLA are watershed area,

3 canopy cover, water current velocity, and Chlorophyll $a$ density, respectively
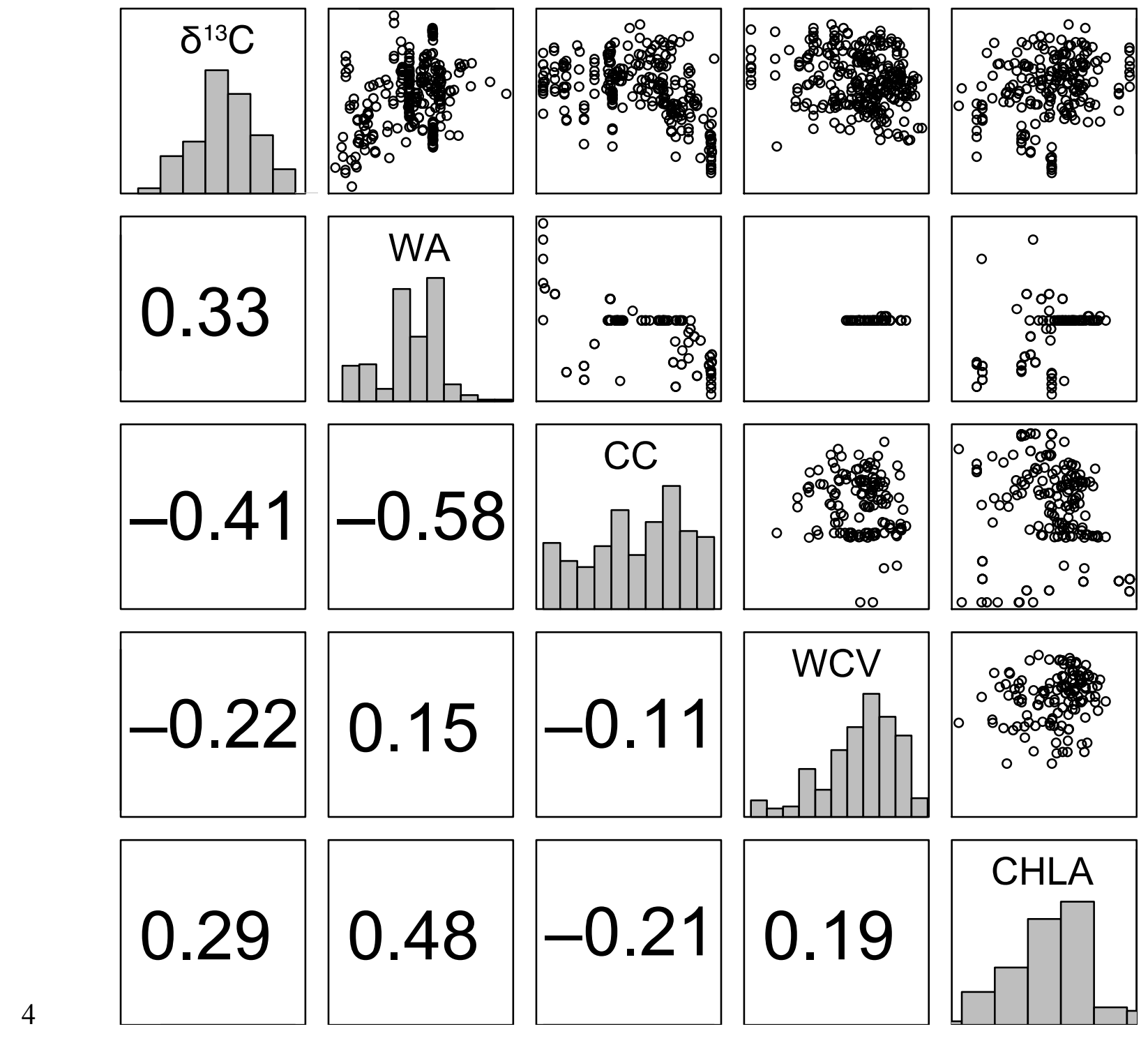
Ishikawa et al. Meta-analyses of lotic periphyton $\delta^{13} \mathrm{C}$

6 Appendix 7: Non-hierarchical null model and hierarchically saturated model. Single asterisks

7 indicate that standardized path-coefficients are significantly different from zero $(\alpha=0.05)$
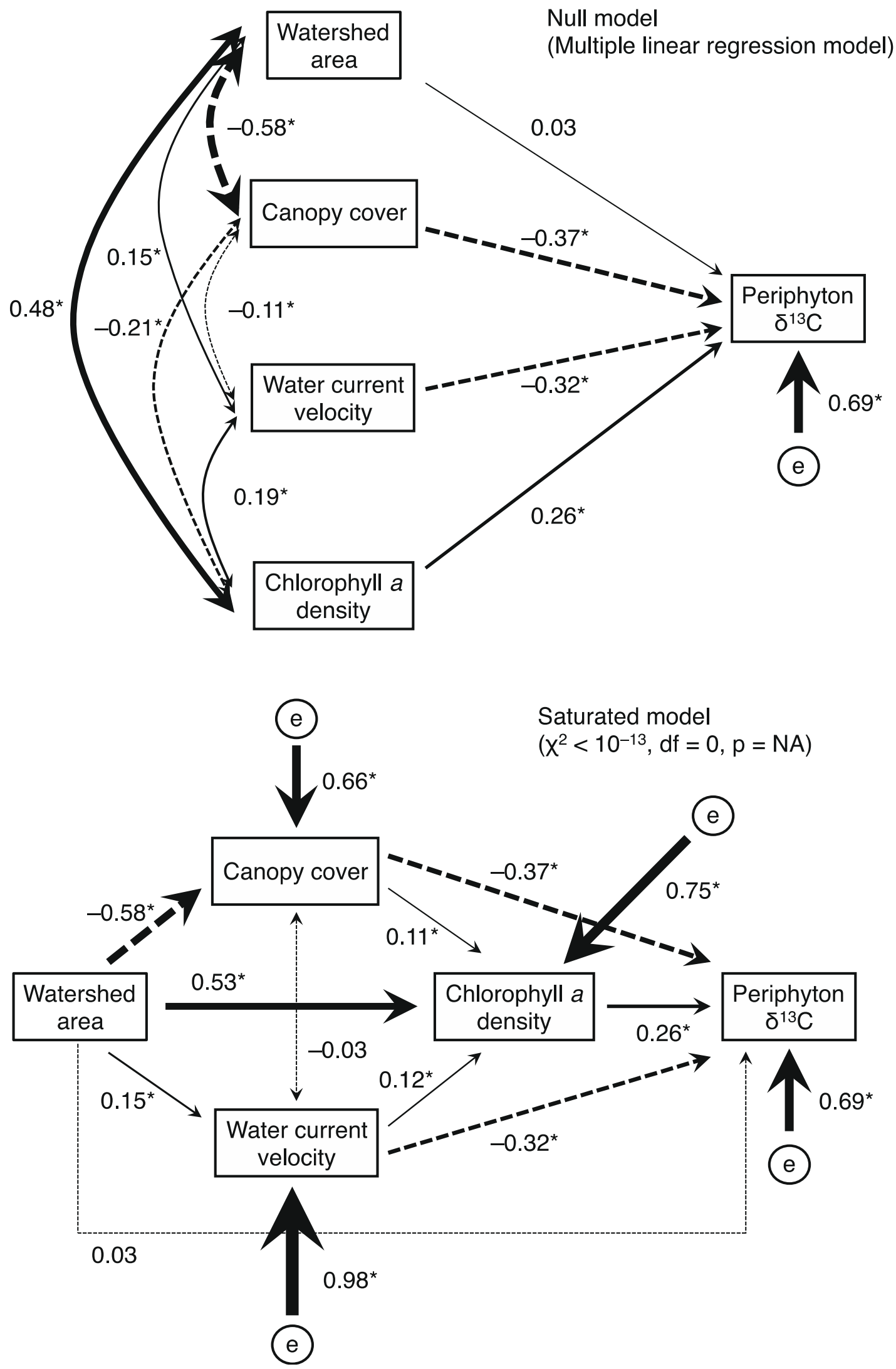